\title{
ORAI2 Down-Regulation Potentiates SOCE and Decreases $A \beta 42$ Accumulation in Human Neuroglioma Cells
}

\author{
Elena Scremin ${ }^{1, \dagger}{ }^{\dagger}$ Mario Agostini ${ }^{1,+}$, Alessandro Leparulo ${ }^{1}\left(\right.$, Tullio Pozzan ${ }^{1,2,3}$, \\ Elisa Greotti ${ }^{1,2, *(\mathbb{D})}$ and Cristina Fasolato $1, *$ (D) \\ 1 Department of Biomedical Sciences, University of Padua, Via U. Bassi 58/B, 35131 Padua, Italy; \\ elena.scremin@studenti.unipd.it (E.S.); agostinimario@icloud.com (M.A.); \\ alessandro.leparulo@unipd.it (A.L.); tullio.pozzan@unipd.it (T.P.) \\ 2 Neuroscience Institute-Italian National Research Council (CNR), Via U. Bassi 58/B, 35131 Padua, Italy \\ 3 Venetian Institute of Molecular Medicine (VIMM), Via G. Orus 2B, 35129 Padua, Italy \\ * Correspondence: elisa.greotti@unipd.it (E.G.); cristina.fasolato@unipd.it (C.F.) \\ + These authors are equal contributors.
}

Received: 9 July 2020; Accepted: 23 July 2020; Published: 25 July 2020

\begin{abstract}
Senile plaques, the hallmarks of Alzheimer's Disease (AD), are generated by the deposition of amyloid-beta (A $\beta)$, the proteolytic product of amyloid precursor protein (APP), by $\beta$ and $\gamma$-secretase. A large body of evidence points towards a role for $\mathrm{Ca}^{2+}$ imbalances in the pathophysiology of both sporadic and familial forms of $\mathrm{AD}$ (FAD). A reduction in store-operated $\mathrm{Ca}^{2+}$ entry (SOCE) is shared by numerous FAD-linked mutations, and SOCE is involved in A $\beta$ accumulation in different model cells. In neurons, both the role and components of SOCE remain quite obscure, whereas in astrocytes, SOCE controls their $\mathrm{Ca}^{2+}$-based excitability and communication to neurons. Glial cells are also directly involved in $A \beta$ production and clearance. Here, we focus on the role of ORAI2, a key SOCE component, in modulating SOCE in the human neuroglioma cell line H4. We show that ORAI2 overexpression reduces both SOCE level and stores $\mathrm{Ca}^{2+}$ content, while ORAI2 downregulation significantly increases SOCE amplitude without affecting store $\mathrm{Ca}^{2+}$ handling. In $\mathrm{A} \beta$-secreting H4-APPswe cells, SOCE inhibition by BTP2 and SOCE augmentation by ORAI2 downregulation respectively increases and decreases $\mathrm{A} \beta 42$ accumulation. Based on these findings, we suggest ORAI2 downregulation as a potential tool to rescue defective SOCE in $\mathrm{AD}$, while preventing plaque formation.
\end{abstract}

Keywords: Alzheimer's Disease; amyloid-beta; neuroglioma cells; ORAI2; calcium entry; stores; SOCE

\section{Introduction}

Both the familial (FAD) and sporadic (SAD) forms of AD are characterized by abnormal accumulation of $A \beta$ which leads to the formation of amyloid deposits, the so-called senile plaques, culminating in synaptic dysfunctions, inflammation and neuronal death [1-3]. A $\beta$ is the product of APP proteolysis performed by two enzymes belonging to the secretase family. The last proteolytic cleavage, leading to A $\beta$ production, is due to either presenilin-1 (PS1) or presenilin-2 (PS2), whose mutations, together with those of APP, are linked to FAD [4]. The enzyme, comprising either PS1 or PS2, called $\gamma$-secretase, produces several proteolytic variants of the A $\beta$ peptide, among which $A \beta 40$ and $A \beta 42$ are the most common isoforms [1-3]. In AD patients as well as in AD mouse models, the stoichiometric ratio between the two variants is altered, favouring the longer version, which is more prone to oligomerisation and deposition [3,5]. Further investigations on the pleiotropic roles of presenilins, led to the discovery of their effect on cellular $\mathrm{Ca}^{2+}$ handling: specifically, when mutated, they alter the endoplasmic reticulum (ER) $\mathrm{Ca}^{2+}$ content as well as the related refilling mechanism, 
known as SOCE [6-22]. A $\beta$ accumulation was variably suggested to be a $\mathrm{Ca}^{2+}$-sensitive event, with SOCE playing a primary role. However, up until now conflicting results have been reported. SOCE inhibition and activation were respectively linked to $A \beta$ augmentation and decrement $[7,23,24]$, whereas other groups reported that SOCE activation induces A $\beta 42$ accumulation [25-27].

SOCE is finely tuned by a biochemical mechanism that is comprised of the ER resident $\mathrm{Ca}^{2+}$ sensor stromal interaction molecule (STIM1/2), and the plasma membrane (PM) channel-forming subunit ORAI (ORAI1/2/3) $[28,29]$. Upon depletion of the store $\mathrm{Ca}^{2+}$ content, STIM proteins oligomerize, leading to the formation of punctae at the ER membrane, which in turn recruit ORAI subunits at the PM. ORAIs are small 25-30 kDa proteins, characterized by four trans-membrane domains; when contacted by STIMs they oligomerize into hexamers to form channels with high $\mathrm{Ca}^{2+}$ selectivity and very low unitary conductance [30] that are responsible of the $\mathrm{Ca}^{2+}$ release-activated $\mathrm{Ca}^{2+}$ current (I $\mathrm{I}_{\mathrm{CAC}}$ ) [31]. Whereas STIM1 and ORAI1 proteins have been deeply investigated [32], the same does not hold true for STIM2, ORAI2 and ORAI3 [28,33]. Only recently has the ORAI2 functionality in the immune system started to be well understood [34-40]. Conversely, in the nervous system, the role of SOCE role and its components remain obscure [41-43]. All three subunits are expressed both in neurons and glial cells [11,37,42,44-47]. In neurons, ORAI1 appears dispensable for SOCE [46], but it has been implicated in neuronal excitability $[45,48]$, whereas ORAI2 seems to be part of a neuronal SOC (nSOC) based on TRPC6 and activated by STIM2, and its activity is impaired in mouse AD models [46]. In glial cells, SOCE plays a major role in the $\mathrm{Ca}^{2+}$-based excitability that characterizes these cells both in culture $[14,42,47,49]$ and in situ $[50,51]$ studies.

In HEK293T cells, ORAI2 was also suggested to be part of the elusive ER $\mathrm{Ca}^{2+}$ leak channel [52], therefore offering a possible link between ER and SOCE alterations found in different FAD models ranging from cell lines, fibroblasts and induced pluripotent stem cells from FAD patients $[19,20,53]$ to neurons and astrocytes from AD mouse models [9-11,14,46,54].

In this study, we focus on the human neuroglioma cell line H4 and its clone H4-APPswe that stably expresses the FAD-linked APP Swedish mutation. These cells are a good model to modulate glial SOCE components and, at the same time, to verify how this modulation affects $A \beta$ accumulation. Of note, glial cells, among the other relevant features also directly participate in $A \beta$ production [55-58], especially upon increased cellular stress caused by different environmental factors [59] and neuroinflammation [60].

In neuroglioma cells, we have characterized the effect of increased and decreased ORAI2 expression on SOCE level and ER $\mathrm{Ca}^{2+}$ content and found that ORAI2 downregulation significantly increases SOCE amplitude while leading to a marked reduction in the A $\beta 42 / A \beta 40$ ratio in the extracellular environment. We suggest ORAI2 as a novel therapeutic target in AD because its downregulation allows for the rescue of SOCE reduction, and at the same time, it reduces $A \beta 42$ secretion by glial cells.

\section{Results}

\subsection{ORAI2 Modulates SOCE in Human Neuroglioma Cells}

In this work, we first addressed whether modulation of ORAI2 protein level modifies $\mathrm{Ca}^{2+}$ dynamics in the human neuroglioma cell line $\mathrm{H} 4$, a widely used cell model for non-neuronal cells of the central nervous system (CNS). In these cells, we carried out experiments with cytosolic aequorin (cytAEQ) to measure $\mathrm{Ca}^{2+}$ changes upon expression of the $\mathrm{Ca}^{2+}$ probe together with human ORAI2 and STIM1, a condition that allows optimal SOCE activation upon store depletion [30,61]. Upon $24 \mathrm{~h}$ from transfection, we evaluated the effect of ORAI2 overexpression on SOCE amplitude by employing the $\mathrm{Ca}^{2+}$-addback protocol [62] (Figure 1). A complete store depletion was obtained by challenging the cells with histamine (Hist, $100 \mu \mathrm{M}$ ) and the reversible blocker of the SERCA pump cyclopiazonic acid $(\mathrm{CPA}, 20 \mu \mathrm{M})$ in a $\mathrm{Ca}^{2+}$-free $\mathrm{mKRB}$, containing EGTA $(0.6 \mathrm{mM})$. Subsequently, the cells were perfused with a mKRB containing $\mathrm{CaCl}_{2}(1 \mathrm{mM})$ and CPA $(20 \mu \mathrm{M})$ to avoid SOCE inactivation. When compared to cells expressing only STIM1 (Figure 1A, black trace, CTRL), the expression of ORAI2-myc (Figure 1A, 
cyan trace) reduced both ER $\mathrm{Ca}^{2+}$ release (Figure 1B) and SOCE (Figure 1C). Quantitatively, significant reductions were obtained both in terms of peak and area under the curve (AUC) $(-34 \pm 8 \%$ and $-35 \pm 14 \%$, for $\mathrm{Ca}^{2+}$ release and $-28 \pm 9 \%$ and $-41 \pm 7 \%$, for SOCE, respectively). Similar data were obtained in $\mathrm{H} 4$ cells expressing ORAI2-myc also tagged with a monomeric Venus (ORAI2-myc-mVenus) (Figure 1A, red trace and Figure 1B,C).
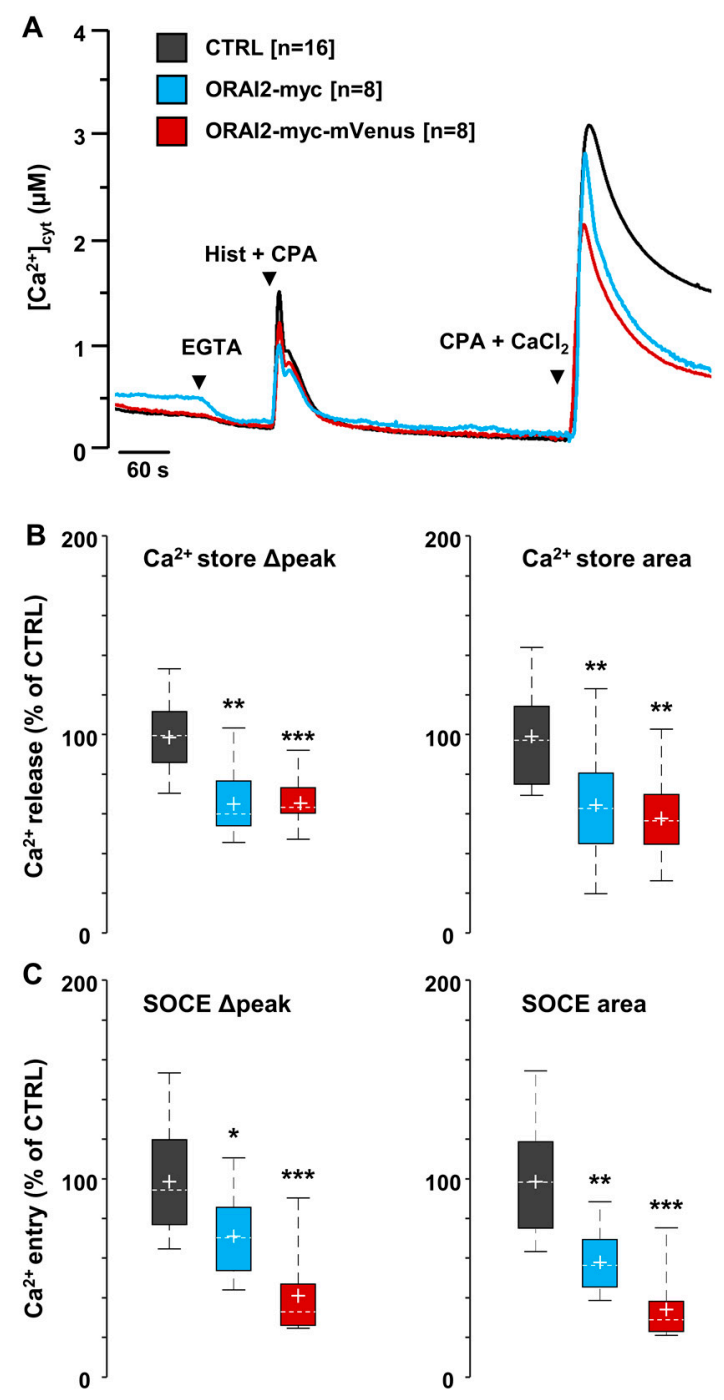

Figure 1. ORAI2 overexpression reduces $\mathrm{ER} \mathrm{Ca}^{2+}$ release and SOCE in $\mathrm{H} 4$ cells. Representative traces of $\mathrm{H} 4$ cells expressing ORAI2-myc or ORAI2-myc-mVenus, STIM1 and cyt-AEQ in a 2:6:1 ratio. (A) Cells were bathed, under perfusion at $37^{\circ} \mathrm{C}$, in $\mathrm{mKRB}$ containing $\mathrm{CaCl}_{2}(1 \mathrm{mM})$. Upon shifting to a $\mathrm{Ca}^{2+}$-free mKRB containing EGTA $(0.6 \mathrm{mM})$, cells were challenged with histamine (Hist, $\left.100 \mu \mathrm{M}\right)$ and CPA $(20 \mu \mathrm{M})$ in the same medium. After $8 \mathrm{~min}$, cells were bathed in $\mathrm{mKRB}$ containing $\mathrm{CaCl}_{2}$ and CPA to detect maximal SOCE amplitude. Boxplots show $\mathrm{Ca}^{2+}$ release (B) and SOCE (C) peak height and AUC, upon baseline subtraction. Data are expressed as percentage of control (CTRL) cells expressing only STIM1 and cyt-AEQ. Coverslips were from at least three independent cell batches. Wilcoxon-Mann-Whitney test $\left({ }^{*} p<0.05 ;{ }^{* *} p<0.01 ;{ }^{* * *} p<0.001\right)$.

Altogether, we can state that the overexpression of ORAI2 together with STIM1 decreases both $\mathrm{ER} \mathrm{Ca}^{2+}$ release and SOCE induced by store depletion. These findings expand previous observations obtained in HEK293T cells, but in the absence of STIM1 overexpression [52]. They also suggest that addition of a C-terminal fluorescent-tag mVenus to ORAI2-myc does not interfere with its functionality, since its expression mimics the $\mathrm{Ca}^{2+}$-related phenotype obtained with the expression of ORAI2-myc. 
By Western blot and immunofluorescence analyses, we verified that, in H4 cells, the two constructs had similar expression levels (Figure 2A,B) and subcellular localization (Figure 2C,D). Both constructs similarly stained a perinuclear structure, likely the Golgi apparatus (GA), a vesicular network and the plasma membrane (PM).

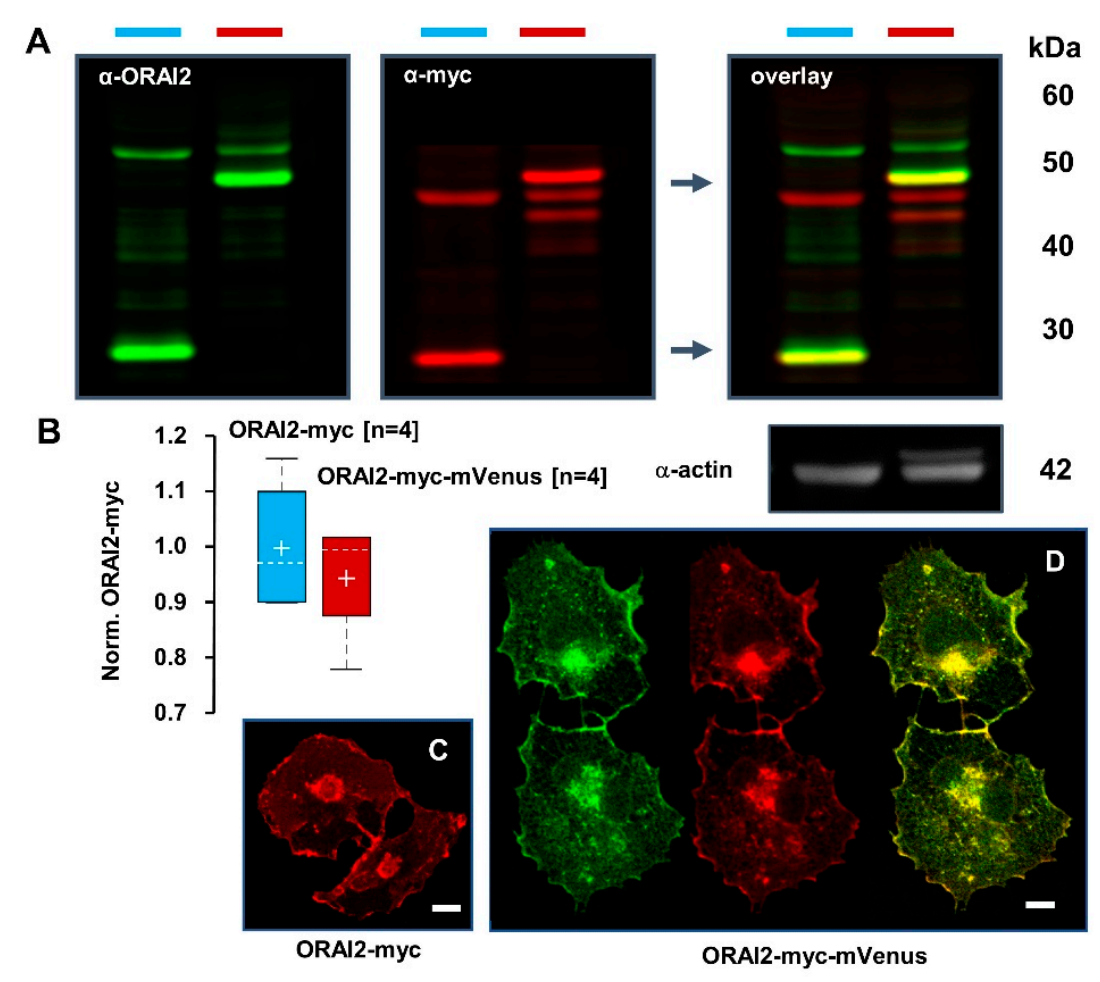

Figure 2. ORAI2-myc and ORAI2-myc-mVenus were similarly expressed in $\mathrm{H} 4$ cells. (A) Western blots from $\mathrm{H} 4$ cells expressing ORAI2-myc or ORAI2-myc-mVenus at $24 \mathrm{~h}$, showing $\alpha$-ORAI2 (left), $\alpha$-myc (middle) and their overlay (right). Yellow color indicates the specific Orai2-myc and Orai2-myc-mVenus bands. (B) Densitometric analysis of ORAI2-myc and ORAI2-myc-mVenus bands at 25 and $50 \mathrm{kDa}$ upon normalization to $\alpha$-actin (Norm. ORAI2-myc). (C, D) Confocal images of ORAI2 localization in $\mathrm{H} 4$ cells upon overexpression of ORAI2-myc (C) or ORAI2-myc-mVenus (D). mVenus fluorescence is shown in green (left), myc-staining in red (middle) and the overlay in yellow (right); scale bars $10 \mu \mathrm{m}$.

Based on siRNA perturbation experiments and computational data, it was also suggested that, in HEK293T cells, ORAI2 contributes to ER Ca ${ }^{2+}$ leak [52]. Our data indicate that, in these cells, endogenous ORAI2 localizes primarily in the early endosomes, as estimated by immunofluorescence studies (Figure S1). The Pearson's coefficient was in fact larger for ORAI2 colocalization with markers of the early endosomes (Figure S1B,C) with respect to a marker of ER (Figure S1A) or late endosomes (Figure S1D), being respectively: $0.26 \pm 0.07$ (ER-GFP), $0.28 \pm 0.04$ (LBPA), $0.44 \pm 0.09$ (rab5) and $0.61 \pm$ 0.07 (EEA1) (Figure S1E). However, only with this latter marker was there a statistically significant difference ( $p<0.05$ compared to ER-GFP and $p<0.01$ compared to LPBA).

To better define ORAI2 localization in $\mathrm{H} 4$ cells, we exploited the overexpression of ORAI2-myc-mVenus with the mCherry protein, targeted to different organelles. In intact $\mathrm{H} 4$ cells, ORAI2-myc-mVenus was spread over a large vesicular network (Figure 3), which was however clearly distinct from ER membranes (Figure 3A) and showed only a minor overlap with the endosomal compartment (Figure 3B). ORAI2 better localized at the PM upon live staining with wheat germ agglutinin (WGA) (Figure 3C). Of note, the PM localization of ORAI2-mVenus was clearly visible upon cell permeabilization (Figure 3D, see also Figure 2D). 


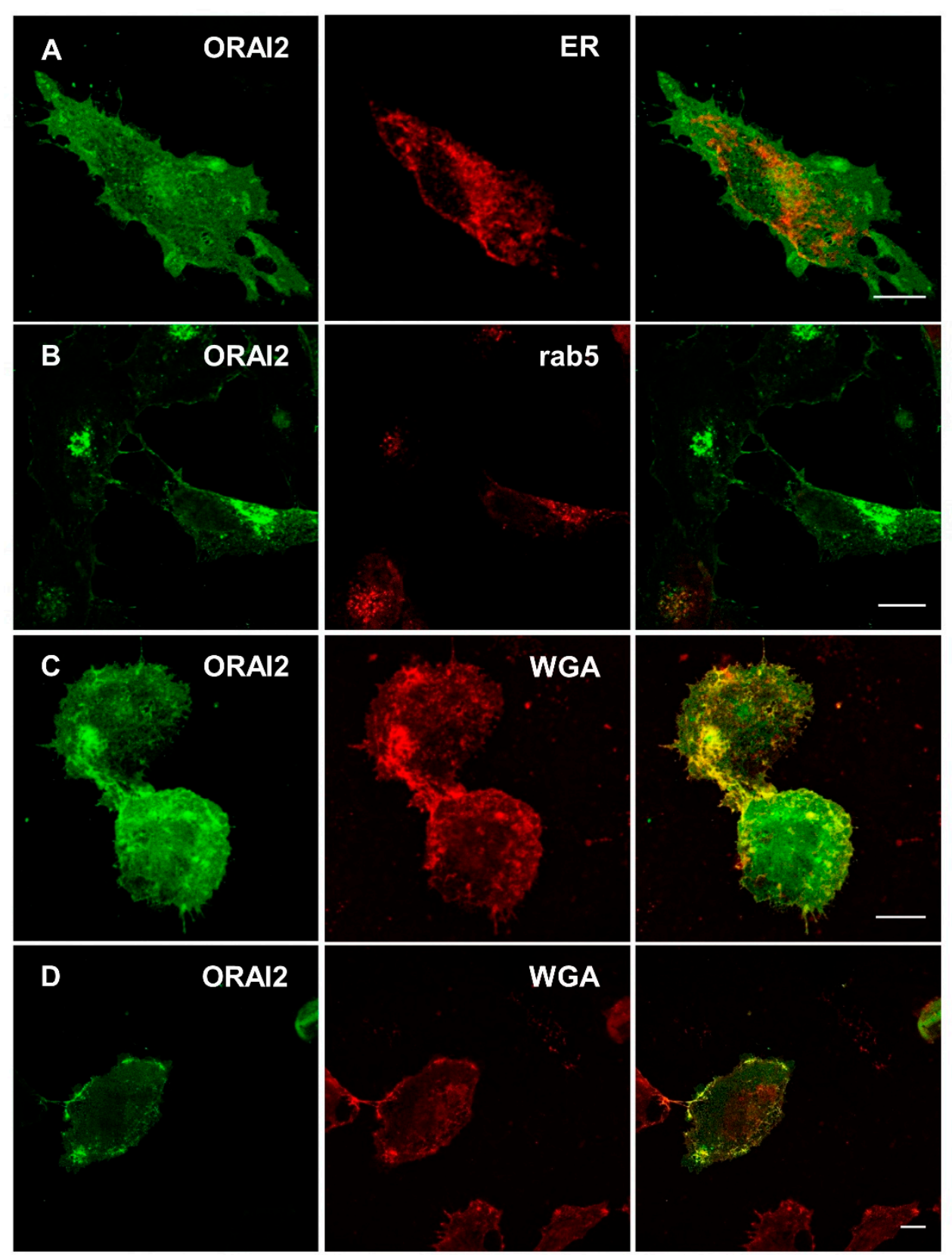

Figure 3. Localization of ORAI2-myc-mVenus in H4 cells. Confocal images of intact $\mathrm{H} 4 \mathrm{cells} 24 \mathrm{~h}$ upon transfection with the cDNA coding for ORAI2-myc-mVenus (green, left) together with ER- (A) or rab5-mCherry (B) (red, middle) and their overlay (right). The cells expressing ORAI2-myc-mVenus were also stained with Wheat Germ Agglutinin (WGA) either before (C) or after cell permeabilization (D); scale bars $10 \mu \mathrm{m}$.

From a functional point of view, we investigated whether the reduction in $\mathrm{ER} \mathrm{Ca}^{2+}$ release, observed in ORAI2-overexpressing cells, was the consequence of a decrease in SOCE amplitude or $\mathrm{IP}_{3} \mathrm{R}$ signalling, or even a direct effect of ORAI2 on ER Ca ${ }^{2+}$ handling. We directly evaluated the effect of ORAI2 at the ER $\mathrm{Ca}^{2+}$ level by expressing ORAI2 together with G-CEPIA1er, a genetically encoded, ER-targeted $\mathrm{Ca}^{2+}$ probe with very low $\mathrm{Ca}^{2+}$ affinity and good dynamic range [63]. Surprisingly, G-CEPIA1er expression in H4 cells was extremely variable being also hampered by a high level of instability and photobleaching. We thus decided to take advantage of HeLa cells for this type of experiment because of a much more stable and reliable G-CEPIA1er signal. In particular, with respect to control (CTRL), void-vector transfected cells, ORAI2-myc overexpression decreased the resting ER 
fluorescence (Figure 4A,B). Since G-CEPIA1er is a non-ratiometric $\mathrm{Ca}^{2+}$ indicator, we obtained an indirect estimation of the ER Ca ${ }^{2+}$ content, calculated as the maximal change obtained after CPA and ionomycin addition (Figure 4A). Upon ORAI2-myc overexpression, the maximal $\mathrm{ER} \mathrm{Ca}^{2+}$ decrease was significantly reduced by about $40 \%$ in ORAI2-myc-expressing cells (Figure 4B).

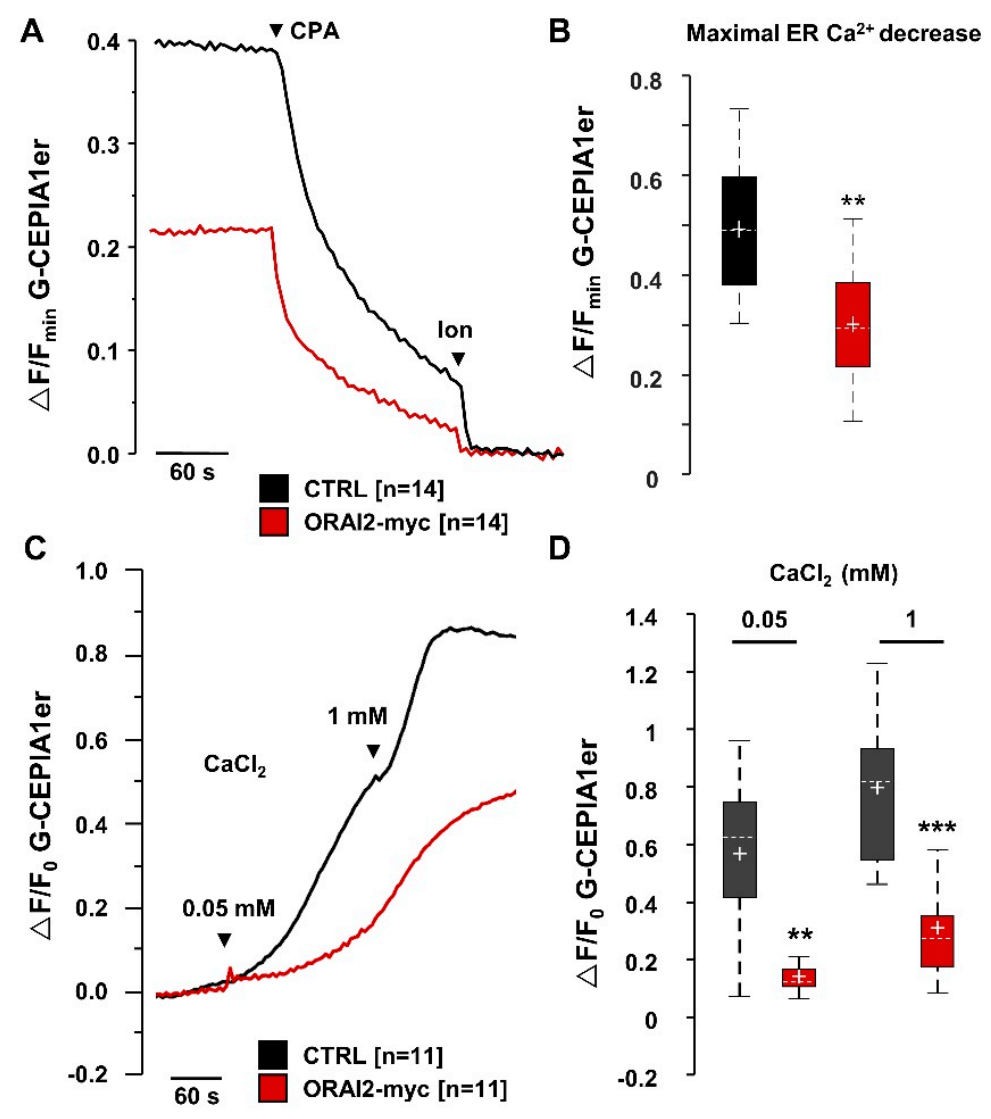

Figure 4. ORAI2-myc overexpression decreases the ER $\mathrm{Ca}^{2+}$ content and refilling process. HeLa cells were co-transfected with the cDNAs coding for ORAI2-myc or with the void-vector (CTRL) and G-CEPIA1er in a 4:1 ratio. (A,B) Cells were bathed for two minutes in $\mathrm{Ca}^{2+}$-free $\mathrm{mKRB}$, containing EGTA $(0.6 \mathrm{mM})$, then challenged with CPA $(20 \mu \mathrm{M})$ and ionomycin (Ion, $1 \mu \mathrm{M})$, where indicated by the arrows. (A) Representative traces of G-CEPIA1er fluorescence (F) normalized to the value measured after ionomycin addition $\left(\mathrm{F}_{\min }\right)$ and expressed as $\left(\triangle \mathrm{F} / \mathrm{F}_{\min }\right)$. (B) Boxplots of the maximal $\mathrm{ER}^{-\mathrm{Ca}^{2+}}$ decrease $\left(\triangle \mathrm{F} / \mathrm{F}_{\mathrm{min}}\right)$ obtained upon $\mathrm{CPA}$ and ionomycin addition, an indication of the ER $\mathrm{Ca}^{2+}$ content $(n=14$, number of coverslips for each condition, from three independent cell batches, Wilcoxon-Mann-Whitney test $\left.{ }^{* *} p<0.01\right)$. (C,D) Cells were pre-depleted with CPA $(20 \mu \mathrm{M})$ in $\mathrm{Ca}^{2+}$-free mKRB, containing EGTA $(0.6 \mathrm{mM})$. Upon CPA washing, cells were exposed to an intracellular solution containing EGTA $(50 \mu \mathrm{M})$. Cells were permeabilized for $20 \mathrm{~s}$ with digitonin $(100 \mu \mathrm{M})$ and store refilling was induced by $\mathrm{CaCl}_{2}$ addition in the presence of ATP $(100 \mu \mathrm{M})$. (C) Representative traces of the maximal fluorescence changes $(\Delta \mathrm{F})$ normalized to the initial basal level $\left(\mathrm{F}_{0}\right)$. (D) Boxplots of $\Delta \mathrm{F} / \mathrm{F}_{0}$ measured upon $\mathrm{CaCl}_{2}$ addition, a rough estimate of the $\mathrm{ER} \mathrm{Ca}^{2+}$ concentration $(n=11$, number of coverslips from three independent cell batches, Wilcoxon-Mann-Whitney test, ${ }^{* *} p<0.01$; ${ }^{* * *} p<0.001$ ).

We also estimated the ER $\mathrm{Ca}^{2+}$ refilling process in permeabilized HeLa cells expressing G-CEPIA1er (Figure 4C). In permeabilized cells, ORAI2 overexpression significantly impaired the ER $\mathrm{Ca}^{2+}$ refilling process by more than $62 \pm 7 \%$ as estimated by maximal $\mathrm{CaCl}_{2}(1 \mathrm{mM})$ addition (Figure $\left.4 \mathrm{D}\right)$. Of note, in ORAI2 overexpressing cells, the rate of $\mathrm{Ca}^{2+}$ uptake was markedly different from control cells even at the initial stage of the refilling process (Figure 4C), suggesting an impairment of the SERCA pump activity rather than an effect on $\mathrm{ER} \mathrm{Ca}^{2+}$ leakage. This latter should in fact become apparent only after 
a certain level of store replenishment. Altogether these findings support the idea that upregulation of ORAI2 impairs the SERCA activity independently of its effect on SOCE level.

\subsection{SOCE Levels and A $\beta$-Secretion in Neuroglioma Cells}

Different groups have suggested a close relationship between cytosolic $\mathrm{Ca}^{2+}$ levels and $\mathrm{A} \beta$ accumulation, however with contrasting results $[7,24,25,27]$. To investigate this issue, we employed the H4-APPswe cell line, that stably express the human APP Swedish mutation (K670/M671L) and accumulates $A \beta$ in the culture medium [64].

By exploiting a pharmacological approach in $\mathrm{A} \beta$-secreting cells, we identified an inverse relationship between SOCE and $A \beta$ accumulation. When H4-APPswe cells were incubated for $24 \mathrm{~h}$ in the culture medium with CPA $(0.5 \mu \mathrm{M})$ or BTP2 $(1 \mu \mathrm{M})$ to activate or inhibit SOCE, respectively, the $\mathrm{A} \beta 42$ that accumulates in the culture medium was either decreased by CPA $(-11 \pm 1 \%, p<0.01)$, or increased by BTP2 $(+11 \pm 4 \%, p<0.05)$, if compared to vehicle (DMSO $0.1 \%$ ) treated cells (Figure S2).

It was demonstrated that ORAI2 knockout increases SOCE in mouse T lymphocytes [35], we thus hypothesized that augmenting SOCE by downregulating ORAI2 would reduce A $\beta$ accumulation by H4-APPswe cells. We firstly checked how ORAI2 modulates SOCE in this cell line. To detect SOCE we thus employed the $\mathrm{Ca}^{2+}$-addback protocol we adopted for $\mathrm{H} 4$ cells, as described in Figure 1. Unfortunately, very heterogeneous $\mathrm{Ca}^{2+}$ increases were observed following $\mathrm{CaCl}_{2}$ addition to H4-APPswe cells upon store depletion with histamine and CPA in $\mathrm{Ca}^{2+}$-free, EGTA-containing mKRB (Figure S3A). Large $\mathrm{Ca}^{2+}$ rises were observed also in the absence of store depletion that were insensitive to a two-minute-treatment with different $\mathrm{Ca}^{2+}$ channel inhibitors, such as $\mathrm{GdCl}_{3}(1 \mu \mathrm{M})$, nimodipine (Nim, $1 \mu \mathrm{M})$ plus verapamil (Ver, $10 \mu \mathrm{M})$, or carbenexolone (CBX, $50 \mu \mathrm{M})$ (Figure S3B). These $\mathrm{Ca}^{2+}$ rises were likely due to $\mathrm{Ca}^{2+}$ entry through other channels, possibly activated by removal of extracellular $\mathrm{Ca}^{2+}$. To overcome this problem, cells were challenged with CPA $(20 \mu \mathrm{M})$ in mKRB in the continuous presence of extracellular $\mathrm{CaCl}_{2}(1 \mathrm{mM})$ (Figure S3C). The contribution of $\mathrm{Ca}^{2+}$ release to $\mathrm{Ca}^{2+}$ rises was evaluated in parallel experiments by adding CPA in a $\mathrm{Ca}^{2+}$-free, EGTA-containing, $\mathrm{mKRB}$ (Figure S3D). Under these conditions, the $\mathrm{Ca}^{2+}$ release, induced by CPA, was rather modest and returned to the resting $\mathrm{Ca}^{2+}$ level in a couple of minutes. Furthermore, given the strong dependence of SOCE on membrane hyperpolarization [31], to reduce the variability due to membrane potential, additional experiments were carried out in $\mathrm{KCl}-\mathrm{mKRB}$, upon substitution of extracellular $\mathrm{NaCl}$ with equimolar $\mathrm{KCl}(100 \mathrm{mM})$. In this condition, to compensate for the reduced driving force for $\mathrm{Ca}^{2+}$ entry, the $\mathrm{CaCl}_{2}$ concentration was increased from 1 to $10 \mathrm{mM}$ [62]. Similarly to experiments in $\mathrm{H} 4$ cells, STIM1 was expressed in the absence (CTRL) or presence of ORAI2. It is worth mentioning that, when store depletion occurs in a $\mathrm{Ca}^{2+}$-containing medium, the initial rate of $\mathrm{Ca}^{2+}$ entry following CPA addition is not indicative solely of SOCE kinetics, since the signal is contaminated by the $\mathrm{Ca}^{2+}$ rise due to $\mathrm{Ca}^{2+}$ release from intracellular stores. We thus estimated differences in SOCE amplitude by $\mathrm{Ca}^{2+}$ peak and AUC, measured at two minutes, when $\mathrm{Ca}^{2+}$ release was practically exhausted (Figure S3D).

In H4-APPswe cells, bathed in $\mathrm{Ca}^{2+}$-containing $\mathrm{mKRB}$, overexpression of ORAI2-myc, together with STIM1, significantly decreased SOCE by about $50 \%$, in terms of both peak and AUC (Figure $\mathrm{S} 4 \mathrm{~A}$ ); similar results were obtained when using KCl-mKRB (Figure S4B). Thus, as shown in H4 cells, SOCE reached lower levels than in control cells upon ORAI2 upregulation. Conversely, ORAI2 downregulation by siRNA (siORAI2) increased SOCE by about $80 \%$, when measured in mKRB (Figure 5A,B) and 70\% in KCl-mKRB (Figure 5C,D), both in terms of peak amplitude and AUC. As expected, ORAI1 downregulation reduced SOCE by more than $60 \%$, in both standard- and KCl-mKRB (Figure S5). 
A

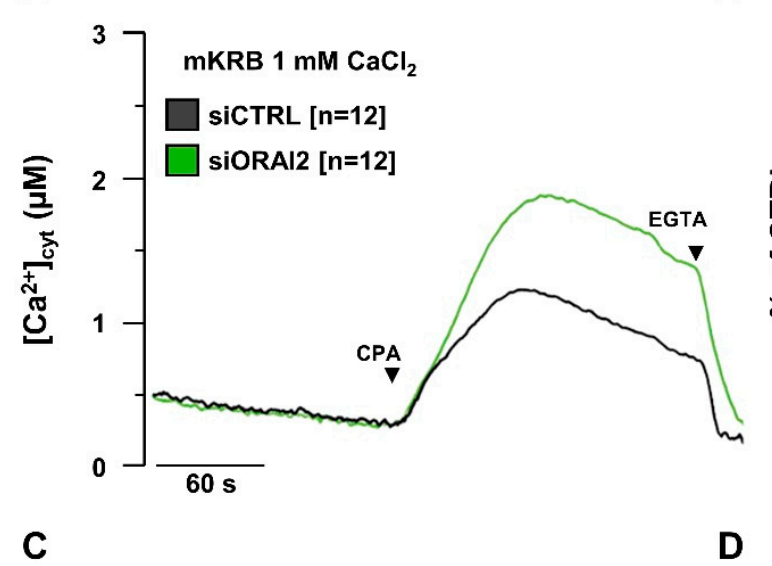

B

D
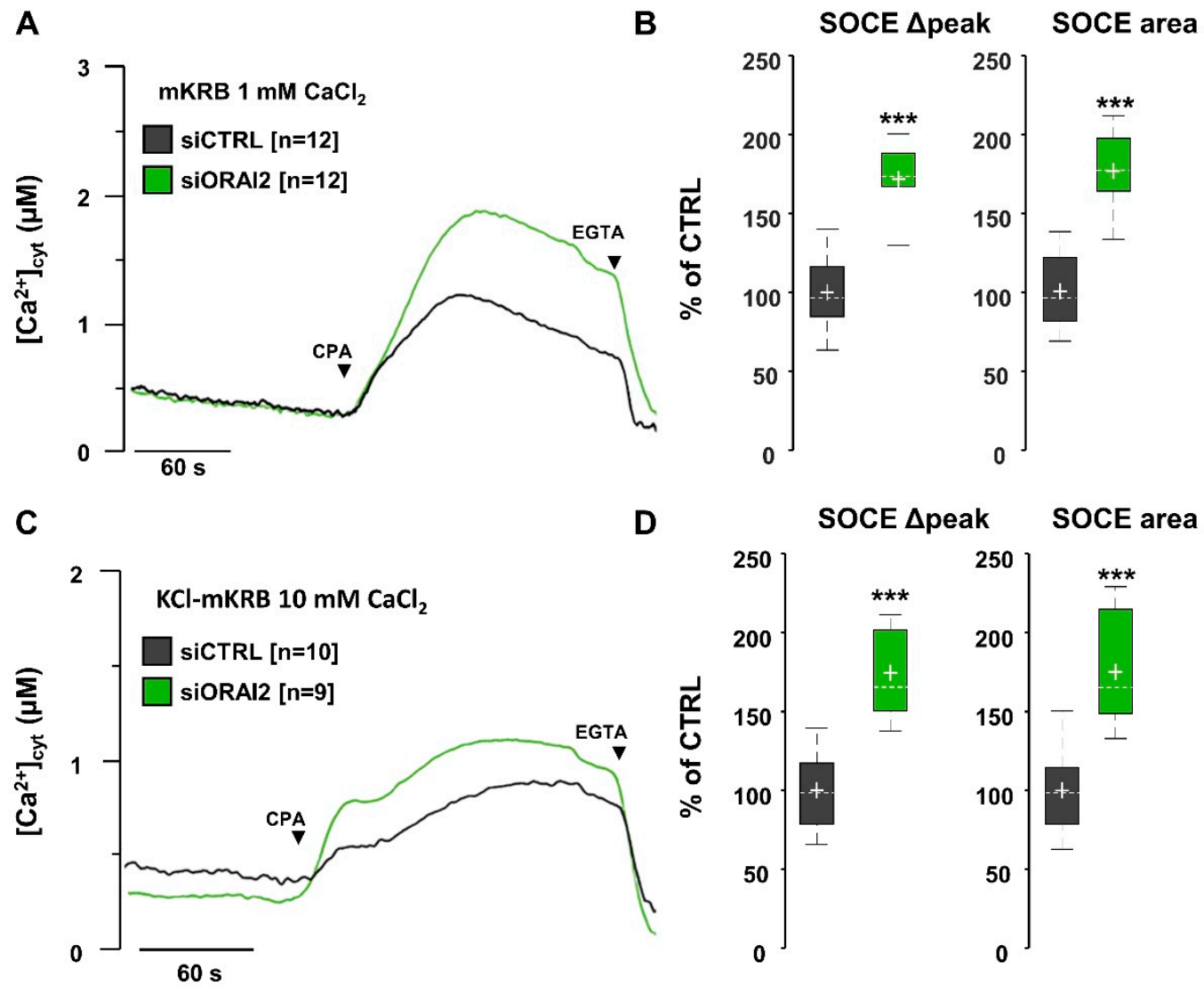

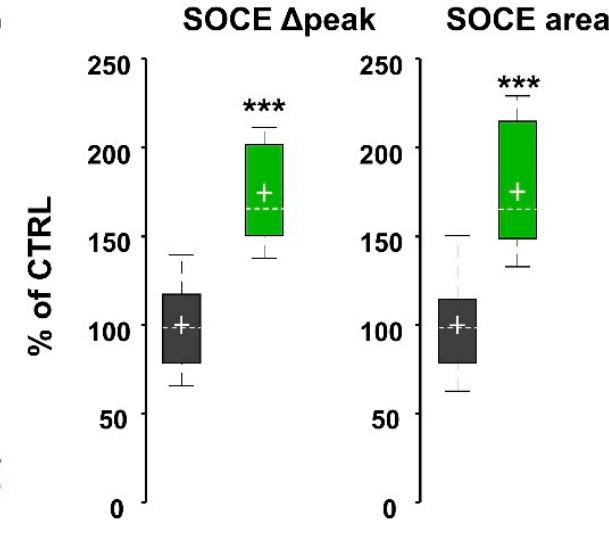

Figure 5. ORAI2 downregulation increases SOCE in H4-APPswe cells. Cells were co-transfected with siCTRL or siORAI2 $(25 \mathrm{nM})$ plus the cDNA coding for cytAEQ. After $48 \mathrm{~h}$, cells were bathed at $37^{\circ} \mathrm{C}$ in mKRB (A,B) or KCl-mKRB (C,D) containing 1 or $10 \mathrm{mM} \mathrm{CaCl}_{2}$, respectively. Cells were then treated with CPA $(20 \mu \mathrm{M})$ to activate SOCE. At the end of the experiment, cells were bathed in $\mathrm{Ca}^{2+}$-free, EGTA-containing medium to stop $\mathrm{Ca}^{2+}$ entry. (A,C) Representative traces are shown for siCTRL (black) and siORAI2 (green) transfected cells, respectively. (B,D) Boxplots of SOCE $\triangle$ peak and AUC, measured within two minutes upon baseline subtraction. Data are expressed as percentage of CTRL, $n=$ number of coverslips, Wilcoxon-Mann-Whitney test ${ }^{* * *} p<0.001$.

To investigate the effect of ORAI2 (plus STIM1) overexpression on the store $\mathrm{Ca}^{2+}$ content of H4-APPswe cells, we induced maximal $\mathrm{Ca}^{2+}$ release by histamine and $\mathrm{CPA}$ in a $\mathrm{Ca}^{2+}$-free, EGTA-containing medium. Similarly, to what observed in H4 cells (Figure 1A,B), ORAI2 overexpression significantly reduced $\mathrm{ER} \mathrm{Ca}^{2+}$ release by $32 \pm 11 \%$ in terms of area (Figure $6 \mathrm{~A}, \mathrm{~B}$ ). Instead, upon ORAI2 downregulation by siRNA, no difference was found in $\mathrm{Ca}^{2+}$ released from the $\mathrm{IP}_{3}$-sensitive stores (Figure 6C,D). 

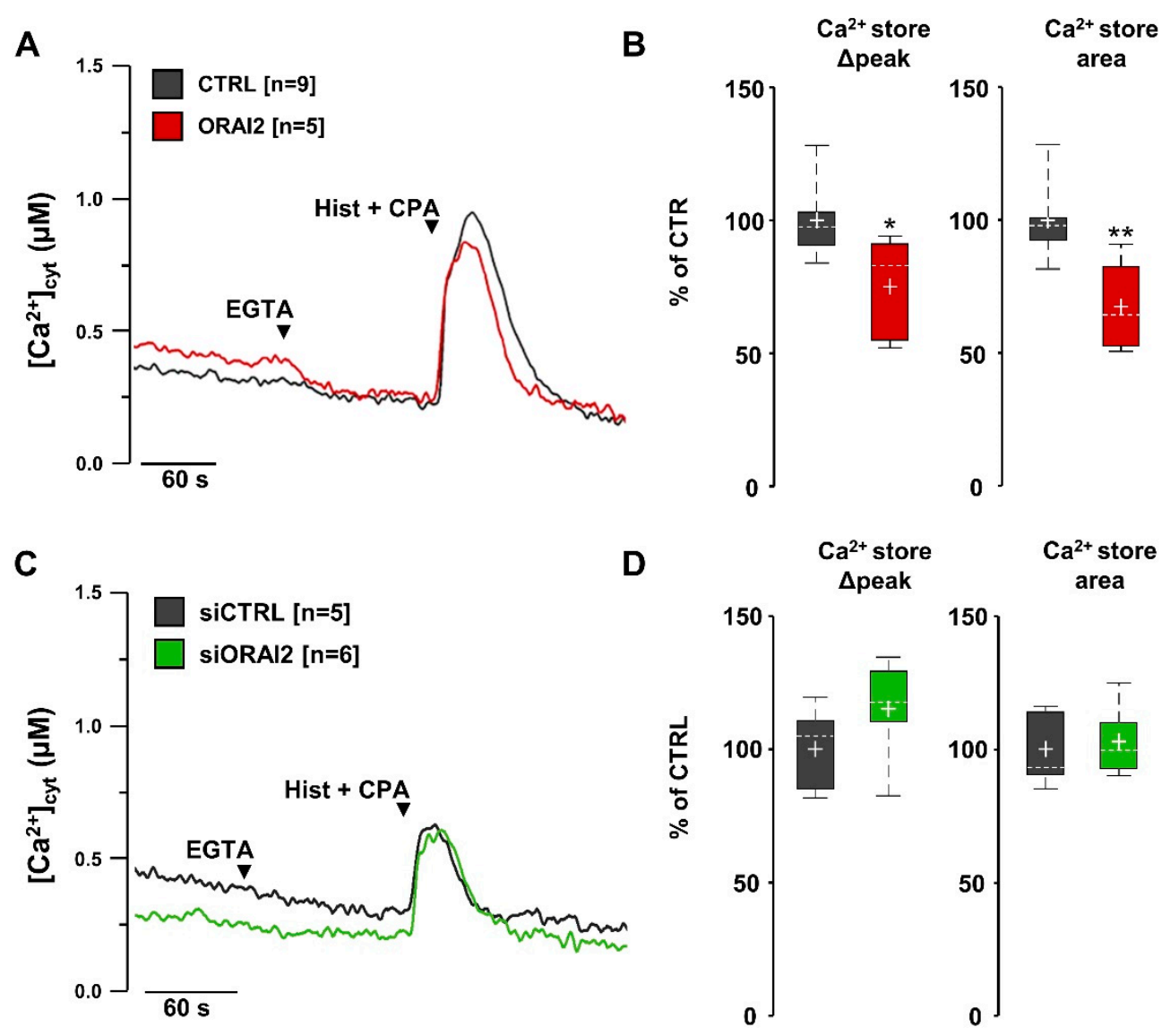

Figure 6. Overexpression, but not downregulation, of ORAI2 modulates the $\mathrm{IP}_{3}$-sensitive $\mathrm{Ca}^{2+}$ stores of H4-APPswe cells. In H4-APPswe cells, overexpression of ORAI2-myc (plus STIM1) decreases the $\mathrm{IP}_{3}$-induced ER Ca ${ }^{2+}$ release while its downregulation by siRNA has no effect. Cells were co-transfected with cyt-AEQ together with void-vector (CTRL) or cDNAs coding for ORAI2 and STIM1 (A,B) or siRNAs (siCTRL or siORAI2) (C,D). Cells were bathed for $2 \mathrm{~min}$ at $37^{\circ} \mathrm{C}$ with $\mathrm{mKRB}$ containing $\mathrm{CaCl}_{2}$ $(1 \mathrm{mM})$, then for one minute with a $\mathrm{Ca}^{2+}$-free $\mathrm{mKRB}$, containing EGTA $(0.6 \mathrm{mM})$, before being challenged with histamine (Hist, $100 \mu \mathrm{M})$ and CPA $(20 \mu \mathrm{M})$ in the same medium, as indicated by the arrows. $(A, C)$ Representative traces for CTRL (black), ORAI2-overexpressing (red) or siORAI2-transfected (green) cells, respectively. (B,D) Boxplots of $\mathrm{Ca}^{2+}$ release, in terms of peak amplitude and AUC, upon baseline subtraction. Data are expressed as percentage of CTRL, $n=$ number of coverslips, Wilcoxon-Mann-Whitney test, ${ }^{*} p<0.05$, ${ }^{* *} p<0.01$.

We also investigated whether ORAI2 overexpression modifies the basal $\mathrm{Ca}^{2+}$ level of H4-APPswe cells. While no difference was found in cells bathed in mKRB containing $\mathrm{CaCl}_{2}(1 \mathrm{mM})(\mathrm{CTRL}=100 \pm 7 \%$, $n=26$; ORAI2 $=112 \pm 6 \%, n=31, p=0.11)$, ORAI2 overexpression almost doubled the resting $\mathrm{Ca}^{2+}$ level of cells bathed in KCl-mKRB, containing high $\mathrm{CaCl}_{2}(10 \mathrm{mM})(\mathrm{CTRL}=100 \pm 13 \%, n=31$; ORAI2 $=176 \pm 14.0 \%, n=32, p<0.001)$. However, due to the intrinsic low sensitivity of cytAEQ in reporting resting $\mathrm{Ca}^{2+}$ levels, this issue was also investigated with nuclear-targeted GCaMP6 (H2B-GCaMP6), a probe with higher $\mathrm{Ca}^{2+}$ affinity with respect to cytAEQ and a very large dynamic range $\left(\mathrm{K}_{\mathrm{d}}=375 \mathrm{nM}\right)$ [65], whose signal is synchronized with the cytosolic one [66]. In mKRB containing $\mathrm{CaCl}_{2}(1 \mathrm{mM})$, ORAI2 overexpression caused a large increase in basal $\mathrm{Ca}^{2+}$ levels (Figure S6A), as estimated by the ratio change occurring at rest upon addition of EGTA $\left(\Delta R=\mathrm{R}_{\mathrm{Ca}}-\mathrm{R}_{\mathrm{EGTA}}\right)$, being equal to $0.7 \pm 0.2$ and $12.4 \pm 1.7$ for CTRL and ORAI2 expressing cells, respectively $(p<0.001)$. In contrast, there was no significant difference in cells upon ORAI2 downregulation (Figure $S 6 \mathrm{~B}, \Delta R=0.23 \pm 0.04$ and $0.55 \pm 0.16$ in siCTRL- and siORAI2-transfected cells, respectively). 
In summary, ORAI2 overexpression modifies SOCE, as well as the store $\mathrm{Ca}^{2+}$ content and resting cytosolic levels. In contrast, ORAI2 downregulation selectively increases SOCE without altering the store $\mathrm{Ca}^{2+}$ content or basal $\mathrm{Ca}^{2+}$ levels. Since our data show that the SOCE inhibitor BTP2 increases A $\beta 42$ accumulation (Figure S2), it is expected that upregulation of SOCE will negatively affect this parameter. ELISA experiments were performed on conditioned media of H4-APPswe cells collected at $48 \mathrm{~h}$ upon transfection with siORAI2 or control siRNA. Under these conditions, the A $\beta 42$ level was reduced by $44 \pm 10 \%$, while the $A \beta 40$ level was increased by $86 \pm 13 \%$, resulting in an approximately $70 \%$ decrease of the $A \beta 42 / A \beta 40$ ratio (Figure 7 ).
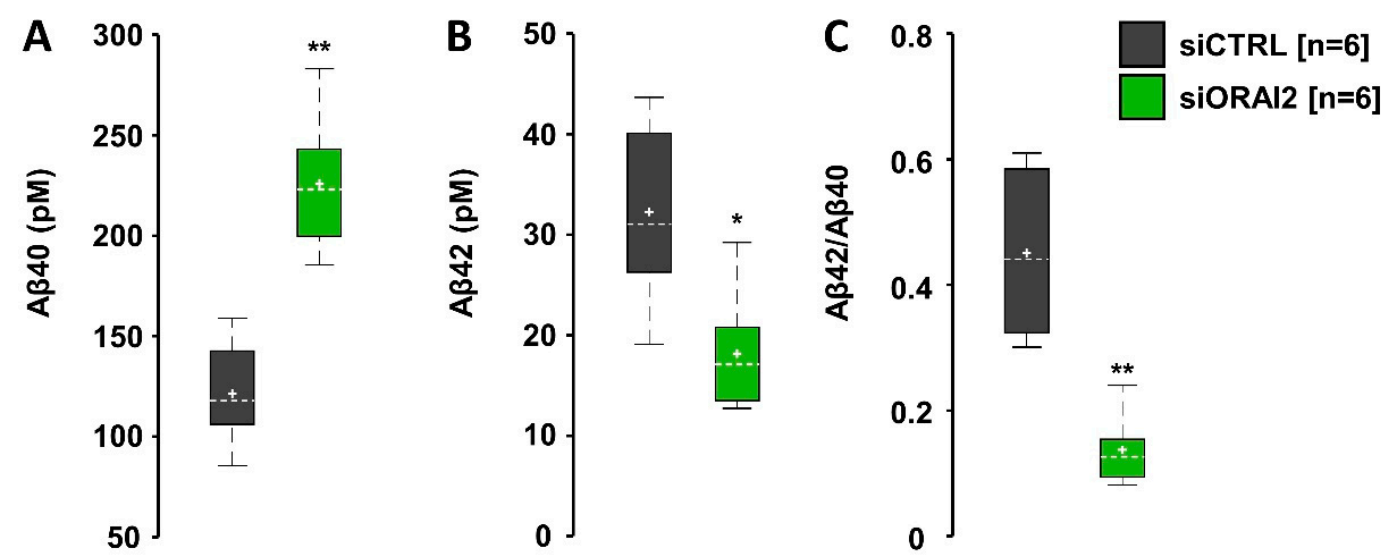

Figure 7. ORAI2 downregulation reduces $A \beta 42 / A \beta 40$ ratio. H4-APPswe cells were transfected with ORAI2-siRNA (siORAI2) or control-siRNA (siCTRL). Boxplots of A $\beta 40$ (A), A $\beta 42$ (B) levels and their ratio $(\mathrm{C})$, detected in the conditioned media at $48 \mathrm{~h}(n=$ number of samples, Wilcoxon-Mann-Whitney test, $\left.{ }^{*} p<0.05 ;{ }^{* *} p<0.01\right)$.

\section{Discussion}

According to recent models, the store-operated $\mathrm{Ca}^{2+}$ entry (SOCE) based on $\mathrm{I}_{\mathrm{CRAC}}$ is due to $\mathrm{Ca}^{2+}$ permeation across hexameric channels formed by ORAI $(1 / 2 / 3)$ subunits $[28,30]$. While the role of ORAI1 has widely been clarified, the contribution of the other subunits to $\mathrm{I}_{\mathrm{CRAC}}$ and SOCE emerged only later $[28,33]$. Thanks to in-depth studies on the immune system, it has elegantly been demonstrated that, in mouse T cells, ORAI2 forms heteromeric channels with ORAI1 and contributes to a reduced $\mathrm{Ca}^{2+}$ permeation through $\mathrm{I}_{\mathrm{CRAC}}[35,39]$. A negative role for ORAI2 on $\mathrm{Ca}^{2+}$ entry was already postulated following overexpression studies in HEK293 cells [67]. In addition, Meyer and co-workers demonstrated that, in HEK293T cells, overexpression of ORAI2 decreases $\mathrm{Ca}^{2+}$ release and content, whereas its downregulation exerts an opposite effect [52].

In this work, we addressed two aspects of ORAI2 modulation of $\mathrm{Ca}^{2+}$ homeostasis: (i) by using three types of model cells, we investigated the effects of ORAI2 levels (overexpression or downregulation) on the $\mathrm{Ca}^{2+}$ content of intracellular stores and the modulation of SOCE; (ii) in the neuroglioma cell line H4-APPswe, we also investigated the effects of SOCE modulation on $\mathrm{A} \beta$ production.

Concerning the first aspect, we here provided evidence that modulation of ORAI2 levels tunes the amplitude of SOCE, with an inverse relationship between ORAI2 expression and $\mathrm{Ca}^{2+}$ entry induced by store depletion. Furthermore, by using different approaches in intact and permeabilized cells, we demonstrated that ORAI2 overexpression decreases the store $\mathrm{Ca}^{2+}$ content, independently of SOCE reduction or $\mathrm{IP}_{3}$-signalling. These findings are in part consistent with data previously reported in HEK-293T cells [52]. However, the co-expression of ORAI2 with an excess of STIM1, as reported in this study, allows us to exclude a dominant negative effect of ORAI2 on endogenous ORA1/STIM1 subunits. At high levels, ORAI2 could in fact sequester a substantial amount of STIM1, preventing effective STIM1-ORAI1 interactions at the PM $[30,61]$. 
It should be noted that, at variance with HEK-293T cells [52], in neuroglioma cells, ORAI2 downregulation by siRNA leaves unchanged the release of $\mathrm{Ca}^{2+}$ from intracellular stores. This last result is not consistent with the hypothesis that endogenous ORAI2 controls the store $\mathrm{Ca}^{2+}$ content by modulating the $\mathrm{ER} \mathrm{Ca}^{2+}$ leak.

In order to try to solve this discrepancy we investigated the subcellular distribution of overexpressed ORAI2 using either a version containing only a myc-tag or one with mVenus-tag fused at the C-terminal. No difference between the two constructs was observed. The overexpression of ORAI2 in $\mathrm{H} 4$ cells resulted in the accumulation of the tagged proteins primarily at the PM level and early endosomes, with no significant overlapping with ER marker. Thus while in $\mathrm{H} 4$ and HeLa the overexpression of ORAI2 produced $\mathrm{Ca}^{2+}$ effects similar to those reported in HEK293T cells, i.e., it reduced the store $\mathrm{Ca}^{2+}$ content and increased the resting $\mathrm{Ca}^{2+}$ level [52], downregulation of the protein left both parameters unchanged. At the moment, the reason for these discrepancies remains unexplained. Yet, the reduction in store $\mathrm{Ca}^{2+}$ level and the slowness in $\mathrm{Ca}^{2+}$ re-uptake, observed in permeabilized cells upon ORAI2 overexpression, together with the lack of ORAI2 colocalization with ER markers suggest that the effect of ORAI2 is likely indirect and not consistent with ORAI2 as an ER leak channel. Furthermore, upon ORAI2 downregulation, the lack of effect on the basal $\mathrm{Ca}^{2+}$ level excludes a direct role of endogenous ORAI2 in controlling the resting $\mathrm{Ca}^{2+}$ concentration, whereas the increase in resting cytosolic $\mathrm{Ca}^{2+}$ level, observed upon overexpression, is consistent with the capability of this subunit to form homomeric functional PM Ca ${ }^{2+}$ channels [35,67], as well as with SOCE activation by chronic reduction in the store $\mathrm{Ca}^{2+}$ content, as originally suggested [52].

SOCE dysregulation has been widely reported among the complex defects that characterize $\mathrm{Ca}^{2+}$ dyshomeostasis in AD [6-8,10-22,46,68,69]. In particular, whereas the role of FAD-linked PS1 and PS2 mutations at the store level was debated [18], the large majority of data converge towards SOCE downregulation, when studied either in cell lines expressing the PS1/2 mutants or in fibroblasts from FAD patients [6,9-13,16,19-21,46] as well as in SAD [10,70]. However, SOCE upregulation was also reported in 3xTg AD mice [14].

In neurons, the identification of both SOCE components and role is still controversial [43], while SOCE seems to play a primary role in modulating the $\mathrm{Ca}^{2+}$-based excitability in astrocytes $[47,49,51,71]$. It is worth noting that astrocytes are also directly involved in $A \beta$ production $[26,55-58]$, while alterations in $\mathrm{Ca}^{2+}$-based excitability has been reported in astrocytes from FAD mouse models $[54,72,73]$.

Over the last two decades, different groups have investigated the relationship between SOCE and $A \beta$ production, with different and often divergent results [7,23-27]. In this work, we took advantage of ORAI2 downregulation to study the relationship between SOCE amplitude and A $\beta$ accumulation while avoiding alterations at the store $\mathrm{Ca}^{2+}$ level. When this relationship was studied by employing SERCA pump inhibitors [25-27] or SERCA2b-siRNA [23] in the presence of extracellular $\mathrm{Ca}^{2+}$, a direct relationship between SOCE activation and $A \beta 42$ accumulation was observed. Yet, it was also reported that pharmacological inhibition of SOCE increases A $\beta 42$ accumulation [7]. Furthermore, SOCE activation by overexpression of ORAI1 or STIM1-D76A, a constitutively active form of STIM1, reduces $A \beta 42$ production [24]. We here show that, in $A \beta$-secreting neuroglioma cells, overnight incubation with CPA or BTP2 (to activate or inhibit SOCE respectively) decreases and increases A $\beta 42$ accumulation, being consistent with an inverse relationship between the two pathways $[7,23,24]$.

The conflicting results obtained with SERCA pump inhibitors by different groups could have different explanations: (i) the use of different cell models; (ii) the different contribution to $\mathrm{Ca}^{2+}$ rises played by $\mathrm{Ca}^{2+}$ release and $\mathrm{Ca}^{2+}$ entry in those cells and (iii) the different roles played by $\mathrm{Ca}^{2+}$ on amyloid processing, $\mathrm{A} \beta$ production and secretion.

ORAI2 downregulation increases SOCE amplitude without modifying the store $\mathrm{Ca}^{2+}$ content thus it permits to test how an increased $\mathrm{Ca}^{2+}$ entry through SOCE influences $\mathrm{A} \beta$ secretion.

In H4-APPswe cells, downregulating ORAI2 by siRNA decreases $A \beta 42$ but increases $A \beta 40$ accumulation, significantly reducing the $A \beta 42 / A \beta 40$ ratio. Altogether, these findings suggest that increased $\mathrm{Ca}^{2+}$ entry through ORAI channels favours the accumulation of the less amyloidogenic 
peptide. It is worth noting that the APP Swedish mutation, by itself, does not change the A $\beta 42 / A \beta 40$ ratio but simply increases the number of secreted peptides, because of its enhancement of $\beta$-secretase cleavage. For this reason, we can consider H4-APPswe cells an acceptable model of A $\beta$ accumulation in SAD.

It is known that $\gamma$-secretase exists in a dynamic equilibrium of conformational states, with the "closed" conformation being associated with the shift of the enzyme cleavage towards the production of longer, neurotoxic $A \beta$ species; of note, the shift to the pathogenic closed conformation is regulated by $\mathrm{Ca}^{2+}[74,75]$. In neurons, the $A \beta 42 / A \beta 40$ ratio is strictly dependent on the pattern of spiking activity [74]. In particular, an increase in burst activity, increases cytosolic $\mathrm{Ca}^{2+}$ and shifts PS1 towards the open conformation thus augmenting the $A \beta 40$ production and reducing the $A \beta 42 / A \beta 40$ ratio [74]. In this work, we provide evidence that increasing $\mathrm{Ca}^{2+}$ levels by SOCE potentiation similarly favours $\mathrm{A} \beta 40$ with respect to $A \beta 42$ secretion; a model explaining the possible linkage between SOCE potentiation, PS conformation, and $A \beta$ production is presented in Figure 8.

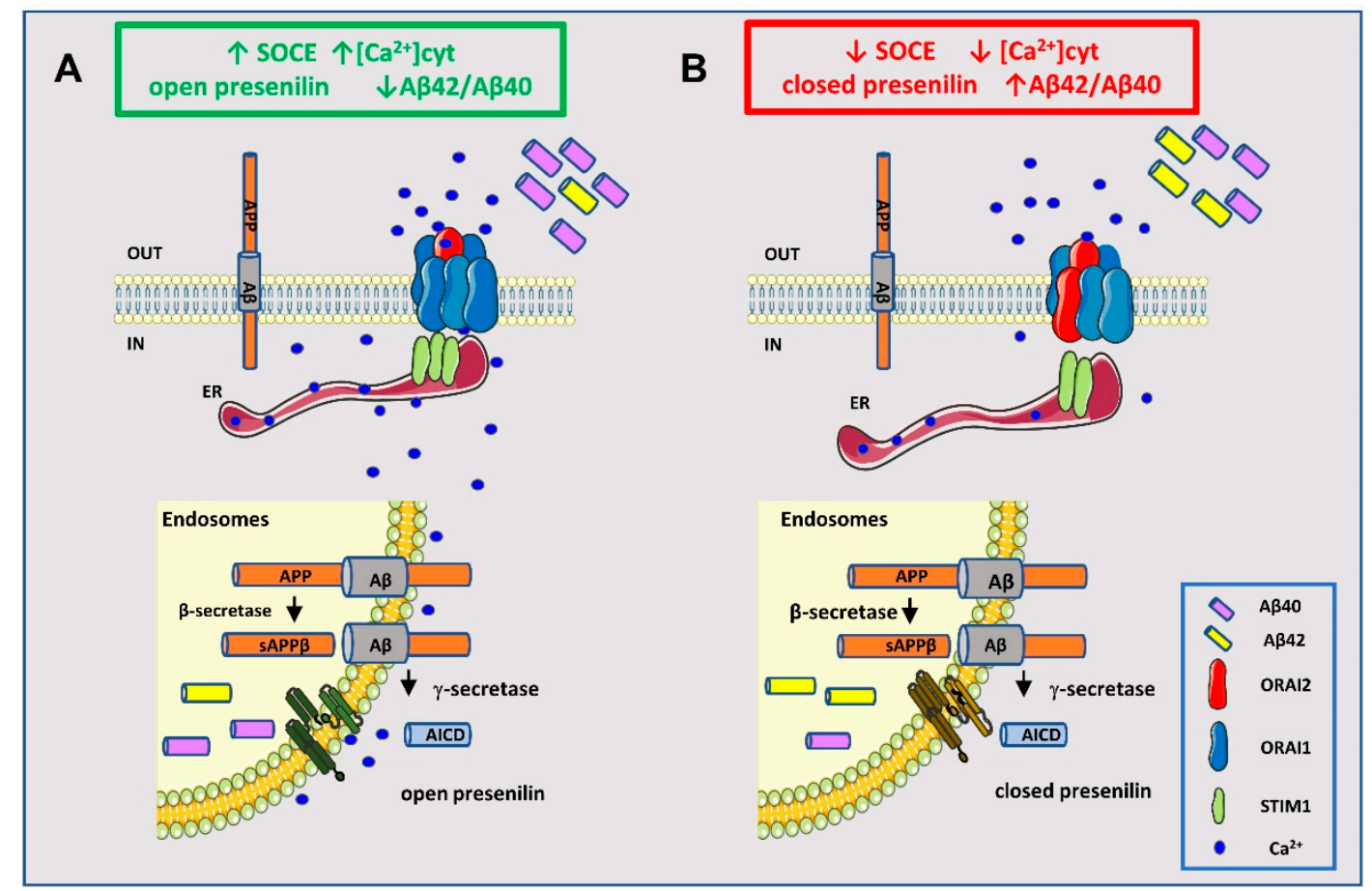

Figure 8. Hypothetical model of the crosstalk between SOCE and A $\beta$ production. (A) Higher SOCE levels by ORAI2 downregulation increase the cytosolic $\mathrm{Ca}^{2+}$ concentration, favouring the open conformation of presenilin and the accumulation of the shorter peptide A $\beta 40$ (74,75).(B) Lower SOCE levels, caused by inhibitors or by reduced STIM1 availability, as observed in $\operatorname{AD}(12,13,70)$, favour the closed conformation of presenilin with the accumulation of the longer peptide A $\beta 42$; AICD (APP intracellular domain).

A sustained increased in $\mathrm{Ca}^{2+}$ entry might also affect the endocytic pathway that controls PS maturation and APP processing through $\gamma$-secretase. It is worth noting that, in addition to its PM localization, ORAI2 is widely distributed in a vesicular network, partially overlapping with the endocytic pathway, thus suggesting a possible role of this protein in the regulation of APP processing at the endosomal level. Here, we demonstrated that ORAI2-myc and ORAI2-myc-mVenus are indistinguishable with respect to $\mathrm{Ca}^{2+}$ handling by neuroglioma cells, thus providing a useful tool to investigate the relationship between APP processing and SOCE in intact cells.

In conclusion, here, we showed that, in A $\beta$-secreting neuroglioma cells, downregulation of ORAI2 potentiates SOCE without altering the store $\mathrm{Ca}^{2+}$ content and decreases the $\mathrm{A} \beta 42 / \mathrm{A} \beta 40$ ratio thus being an interesting tool to restore defective $\mathrm{Ca}^{2+}$ entry associated to $\mathrm{AD}[9,10,54,76]$, while preventing 
amyloid seeding, given the direct correlation of this latter with the $A \beta 42 / A \beta 40$ ratio. Altogether, our data support the idea that SOCE, and particularly ORAI2, could be a potential therapeutic target in AD.

\section{Materials and Methods}

\subsection{Cell Culture and Transfection}

H4, H4-APPswe, HEK293T, and HeLa cells were grown in DMEM (Dulbecco's Modified Eagle Medium, Merck Life Science, Milan, Italy) containing 10\% FCS (fetal calf serum, Merck Life Science, Milan, Italy), supplemented with L-glutamine $(2 \mathrm{mM})$, penicillin $(100 \mathrm{U} / \mathrm{mL})$, and streptomycin $(100 \mu \mathrm{g} / \mathrm{mL})$, in a humidified atmosphere containing $5 \% \mathrm{CO}_{2}$. For cytAEQ and immunofluorescence experiments, cells were seeded onto $13 \mathrm{~mm}$ glass coverslips and cultured into 24-well plates. For fluorescent probe experiments, cells were seeded onto $24 \mathrm{~mm}$ glass coverslips and cultured into 6-well plates. For Western blot and Enzyme-Linked ImmunoSorbent Assay (ELISA) experiments, cells were seeded directly into 6-well plates. Transfection was performed at $60-70 \%$ confluence with the cDNA coding for the proteins of interest or the void-vector (pcDNA3.1) and the cDNA coding for the $\mathrm{Ca}^{2+}$ probe in a 4:1 ratio or rab5-mCherry (Addgene \#49201) or ER-mCherry (Addgene Plasmid \#55041) in a 1:1ratio using TransIT LT1 Transfection Reagent (Mirus, MIR 2305) (3 $\mu \mathrm{L} / \mu \mathrm{g}$ DNA). For Wheat Germ Agglutinin (WGA, Texas Red ${ }^{\circledR}$-X Conjugate, Thermo Fisher scientific, Monza, Italy, \#W21405) staining, cells were incubated for $10 \mathrm{~min}$ at $37^{\circ} \mathrm{C}$ in a $\mathrm{Ca}^{2+}$-containing mKRB supplemented with WGA $(5 \mu \mathrm{M})$, then washed in PBS and fixed. For RNAi experiments, cells were transfected using Lipofectamine RNAi-MAX transfection reagent in complete culture medium (Thermo Fisher scientific, Monza, Italy, \#13778150) (3 $\mu \mathrm{L} / \mathrm{mL}$ ). siRNAs (human Orai2 MISSION esiRNA EHU060251, human Orai1 MISSION esiRNA EHU120081, Universal Negative Control \#1 MISSION siRNA SIC001) were used at a final concentration of $25 \mathrm{nM}$. Western blots and immunofluorescence were usually performed $24 \mathrm{~h}$ after transfection, while $\mathrm{Ca}^{2+}$ measurements were performed 24 and $48 \mathrm{~h}$ after transfection, for overexpression and downregulation, respectively.

\subsection{Aequorin Measurements}

Upon transfection, the cells were incubated for $1 \mathrm{~h}$ with coelenterazine $(5 \mu \mathrm{M})$ in modified Krebs-Ringer Buffer (mKRB, composition in mM: $140 \mathrm{NaCl}, 2.8 \mathrm{KCl}, 2 \mathrm{MgCl}_{2}, 10$ 4-[2-hydroxyethyl]-1piperazineethanesulfonic acid - HEPES -, 10 glucose, $\mathrm{pH} 7.4$ at $\left.37^{\circ} \mathrm{C}\right)$ containing $\mathrm{CaCl}_{2}(1 \mathrm{mM})$ and then transferred to the perfusion chamber. The cytAEQ measurements were carried out in mKRB containing $\mathrm{CaCl}_{2}(1 \mathrm{mM})$ at $37^{\circ} \mathrm{C}$. Where indicated, in $\mathrm{mKRB}, \mathrm{NaCl}(100 \mathrm{mM})$ was substituted by $\mathrm{KCl}(100 \mathrm{mM})(\mathrm{KCl}-\mathrm{mKRB}$ composition in mM: $43 \mathrm{NaCl}, 100 \mathrm{KCl}, 2 \mathrm{MgCl} 2,10 \mathrm{HEPES}, 10$ glucose, $\mathrm{pH} 7.4$ at $37^{\circ} \mathrm{C}$ ) to set to zero the membrane potential. Agonists and other drugs were added to the same medium, as specified in the figures. The experiments were terminated by lysing the cells with digitonin $(100 \mu \mathrm{M})$ in a hypotonic $\mathrm{Ca}^{2+}$-rich solution $\left(10 \mathrm{mM} \mathrm{CaCl}_{2}\right)$ in $\mathrm{H}_{2} \mathrm{O}$ to discharge the remaining unused AEQ pool. Signal detection and analysis was carried out as previously described [77].

\section{3. $\mathrm{Ca}{ }^{2+}$ Imaging}

HeLa cells expressing G-CEPIA1er fluorescent probe and H4-APPswe cells expressing H2B-GCaMP6 fluorescent probe were bathed in mKRB containing $\mathrm{CaCl}_{2}(1 \mathrm{mM})$ at $37^{\circ} \mathrm{C}$. When indicated, cells were bathed in a $\mathrm{Ca}^{2+}$-free $\mathrm{mKRB}$ containing EGTA $(0.6 \mathrm{mM})$ or in a $\mathrm{Ca}^{2+}$-free intracellular solution also containing EGTA $(0.05 \mathrm{mM})$ of the following composition in $\mathrm{mM}(130 \mathrm{KCl}$, $10 \mathrm{NaCl}, 1 \mathrm{MgCl}_{2}, 2$ succinic acid and 20 HEPES, pH 7.0 at $37^{\circ} \mathrm{C}$ ). Cells were analyzed using an inverted microscope (Zeiss Axiovert 100, Jena, Germany) with a Fluar 40X oil objective (NA 1.30). Excitation light (480 nm for G-CEPIA1er, 410/10 nm and 475/10 nm for H2B-GCaMP6) was produced by a monochromator (Polychrome V; TILL Photonics, Graefelting, Germany) and passed through a dichroic mirror DRLP (505 ext XF73). The emitted fluorescence was collected by a bandpass filter (500-530 nm). Images were acquired using a cooled CCD camera (SensiCam QE, PCO, Kelheim, 
Germany). All filters and dichroic mirrors were from Chroma Technologies (Bellow Falls, VT, USA). Images were collected at $0.2 \mathrm{~Hz}$ with $200 \mathrm{~ms}$ exposure time. Cells were mounted into an open-topped chamber and maintained in mKRB medium. Additions were made in the same or different medium, as specified in the figures. G-CEPIA1er experiments: data are presented as $\Delta F / F_{0}$ or $\Delta F / F_{\min }$ values (where $\Delta \mathrm{F}$ are fluorescence changes at any time, $\mathrm{F}_{\mathrm{min}}$ is the fluorescence value upon ionomycin addition and $F_{0}$ the baseline value). H2B-GCaMP6 experiments: data are presented as $\Delta R$ values (where $\Delta R$ is the change of the $\mathrm{F}_{470} / \mathrm{F}_{410}$ emission intensity ratio at any time.

\subsection{Materials}

CPA and ionomycin were from Calbiochem (Merck Life Science, Milan, Italy). All other materials were analytical of the highest available grade were purchased from Sigma-Aldrich (Merck Life Science, Milan, Italy).

\subsection{Statistical Analyses}

Data were analyzed using Origin 8.0 SR6 (OriginLab Corporation, Northampton, MA, USA) and Microsoft Excel 2010 (Microsoft Corporation, Redmond, WA, USA). All data are representative of at least 3 independent experiments. Numerical values presented throughout the text are mean \pm S.E.M. ( $n=$ number of independent experiments or cells, as indicated). Significance was evaluated by the non-parametric Kruskal-Wallis test. Where the Kruskal-Wallis test resulted in the existence of a pair of different populations, differences between means were tested with the Wilcoxon-Mann-Whitney test. Boxplots show median, mean, the 25th and 75th percentile of the distributions, while whiskers indicate the upper and lower extremes. ${ }^{*} p<0.05,{ }^{* *} p<0.01,{ }^{* * *} p<0.001$.

Supplementary Materials: Supplementary materials can be found at http://www.mdpi.com/1422-0067/21/15/ 5288/s1. Figure S1. Endogenous ORAI2 localizes to the early endosomal compartment in HEK293T cells. Figure S2. Inverse relationship between SOCE modulation and A $\beta 42$ secretion Figure S3. SOCE protocols in H4-APPswe cells. Figure S4. ORAI2 overexpression reduces SOCE in H4-APPswe. Figure S5. ORAI1 downregulation reduces SOCE in H4-APPSwe cells ORAI2 overexpression reduces SOCE in H4-APPswe. Figure S6. Effects of ORAI2 on basal $\mathrm{Ca}^{2+}$ levels in H4-APPswe cells.

Author Contributions: Conceptualization, C.F.; data curation, M.A., E.S., A.L. and E.G.; formal analysis, E.S., M.A, E.G. and A.L.; funding acquisition, T.P. and C.F.; investigation, M.A., E.S. and E.G.; methodology, M.A., E.S. and E.G.; project administration, E.G. and C.F.; resources, T.P. and C.F.; software, E.S.; M.A.; E.G. and A.L.; supervision, T.P., E.G. and C.F.; validation, M.A., E.S., A.L., E.G. and C.F.; visualization M.A., E.S., A.L. and E.G.; writing—original draft preparation, C.F.; writing—review and editing, E.S., M.A., E.G., A.L., T.P. and C.F.; All authors have read and agreed to the published version of the manuscript.

Funding: This work was funded by the Ministry of Education, University and Research (MIUR) to T.P. and C.F.; Euro-BioImaging-Roadmap/ESFRI from European Commission to T.P.; Fondazione Cassa di Risparmio di Padova e Rovigo (CARIPARO Foundation) Excellence project 2017 (2018/113) to T.P.; UniPD Project 2015 (CPDA157003), PRIN-2015W2N883_001 and PRIN-20175C22WM to C.F.; UniPD funds for research equipment-2015. ES was supported by a CARIPARO Ph.D. fellowship 2016-2019. As post-docs, E.S. was supported by PRIN-20175C22WM and A.L. by UniPD (CPDA157003) and BIRD 2017 grants to C.F.

Acknowledgments: We are grateful to P. Magalhães for critically reading the manuscript, D. Pendin for helpful suggestions, C. Brognara and L. Hendrickx for helping with some experiments.

Conflicts of Interest: The authors declare no conflict of interest.

\section{References}

1. Hardy, J.; Allsop, D. Amyloid deposition as the central event in the aetiology of Alzheimer's disease. Trends Pharmacol. Sci. 1991, 12, 383-388. [CrossRef]

2. Hardy, J.; Higgins, G. Alzheimer's disease: The amyloid cascade hypothesis. Science 1992, 256, 184-185. [CrossRef]

3. Selkoe, D.J.; Hardy, J. The amyloid hypothesis of Alzheimer's disease at 25 years. Embo. Mol. Med. 2016, 8, 595-608. [CrossRef] [PubMed] 
4. Chávez-Gutiérrez, L.; Szaruga, M. Mechanisms of neurodegeneration — Insights from familial Alzheimer's disease. Semin. Cell Dev. Biol. 2020. [CrossRef] [PubMed]

5. Lesné, S.; Koh, M.T.; Kotilinek, L.; Kayed, R.; Glabe, C.G.; Yang, A.; Gallagher, M.; Ashe, K.H. A specific amyloid- $\beta$ protein assembly in the brain impairs memory. Nature 2006, 440, 352-357. [CrossRef] [PubMed]

6. Leissring, M.A.; Akbari, Y.; Fanger, C.M.; Cahalan, M.D.; Mattson, M.P.; LaFerla, F.M. Capacitative calcium entry deficits and elevated luminal calcium content in mutant presenilin-1 knockin mice. J. Cell. Biol. 2000, 149, 793-798. [CrossRef]

7. Yoo, A.S.; Cheng, I.; Chung, S.; Grenfell, T.Z.; Lee, H.; Pack-Chung, E.; Handler, M.; Shen, J.; Xia, W.; Tesco, G.; et al. Presenilin-Mediated Modulation of Capacitative Calcium Entry. Neuron 2000, 27, 561-572. [CrossRef]

8. Boyle, J.P.; Hettiarachchi, N.T.; Wilkinson, J.A.; Pearson, H.A.; Scragg, J.L.; Lendon, C.; Al-Owais, M.M.; Kim, C.B.; Myers, D.M.; Warburton, P.; et al. Cellular consequences of the expression of Alzheimer's disease-causing presenilin 1 mutations in human neuroblastoma (SH-SY5Y) cells. Brain Res. 2012, 1443, 75-88. [CrossRef]

9. Greotti, E.; Capitanio, P.; Wong, A.; Pozzan, T.; Pizzo, P.; Pendin, D. Familial Alzheimer's disease-linked presenilin mutants and intracellular $\mathrm{Ca}^{2+}$ handling: A single-organelle, FRET-based analysis. Cell Calcium 2019, 74, 44-56. [CrossRef]

10. Sun, S.; Zhang, H.; Liu, J.; Popugaeva, E.; Xu, N.-J.; Feske, S.; White, C.L.; Bezprozvanny, I. Reduced Synaptic STIM2 Expression and Impaired Store-Operated Calcium Entry Cause Destabilization of Mature Spines in Mutant Presenilin Mice. Neuron 2014, 82, 79-93. [CrossRef]

11. Zhang, H.; Wu, L.; Pchitskaya, E.; Zakharova, O.; Saito, T.; Saido, T.; Bezprozvanny, I. Neuronal Store-Operated Calcium Entry and Mushroom Spine Loss in Amyloid Precursor Protein Knock-In Mouse Model of Alzheimer's Disease. J. Neurosci. 2015, 35, 13275-13286. [CrossRef] [PubMed]

12. Tong, B.C.-K.; Lee, C.S.-K.; Cheng, W.-H.; Lai, K.-O.; Kevin Foskett, J.; Cheung, K.-H. Familial Alzheimer's disease-associated presenilin 1 mutants promote $\gamma$-secretase cleavage of STIM1 to impair store-operated $\mathrm{Ca}^{2+}$ entry. Sci. Signal. 2016, 9, ra89. [CrossRef] [PubMed]

13. Bojarski, L.; Pomorski, P.; Szybinska, A.; Drab, M.; Skibinska-Kijek, A.; Gruszczynska-Biegala, J.; Kuznicki, J. Presenilin-dependent expression of STIM proteins and dysregulation of capacitative $\mathrm{Ca}^{2+}$ entry in familial Alzheimer's disease. Biochim. Biophys. Acta 2009, 1793, 1050-1057. [CrossRef] [PubMed]

14. Ronco, V.; Grolla, A.A.; Glasnov, T.N.; Canonico, P.L.; Verkhratsky, A.; Genazzani, A.A.; Lim, D. Differential deregulation of astrocytic calcium signalling by amyloid- $\beta$, TNF $\alpha$, IL-1 $\beta$ and LPS. Cell Calcium 2014, 55, 219-229. [CrossRef]

15. Herms, J.; Schneider, I.; Dewachter, I.; Caluwaerts, N.; Kretzschmar, H.; Van Leuven, F. Capacitive Calcium Entry Is Directly Attenuated by Mutant Presenilin-1, Independent of the Expression of the Amyloid Precursor Protein. J. Biol. Chem. 2003, 278, 2484-2489. [CrossRef]

16. Bezprozvanny, I. Presenilins and Calcium Signaling-Systems Biology to the Rescue. Sci. Signal. $2013,6$. [CrossRef]

17. Honarnejad, K.; Herms, J. Presenilins: Role in calcium homeostasis. Int. J. Biochem. Cell Biol. 2012, 44, 1983-1986. [CrossRef]

18. Shilling, D.; Mak, D.-O.D.; Kang, D.E.; Foskett, J.K. Lack of Evidence for Presenilins as Endoplasmic Reticulum $\mathrm{Ca}^{2+}$ Leak Channels. J. Biol. Chem. 2012, 287, 10933-10944. [CrossRef]

19. Giacomello, M.; Barbiero, L.; Zatti, G.; Squitti, R.; Binetti, G.; Pozzan, T.; Fasolato, C.; Ghidoni, R.; Pizzo, P. Reduction of $\mathrm{Ca}^{2+}$ stores and capacitative $\mathrm{Ca}^{2+}$ entry is associated with the familial Alzheimer's disease presenilin-2 T122R mutation and anticipates the onset of dementia. Neurobiol. Dis. 2005, 18, 638-648. [CrossRef]

20. Zatti, G.; Burgo, A.; Giacomello, M.; Barbiero, L.; Ghidoni, R.; Sinigaglia, G.; Florean, C.; Bagnoli, S.; Binetti, G.; Sorbi, S.; et al. Presenilin mutations linked to familial Alzheimer's disease reduce endoplasmic reticulum and Golgi apparatus calcium levels. Cell Calcium 2006, 39, 539-550. [CrossRef]

21. Brunello, L.; Zampese, E.; Florean, C.; Pozzan, T.; Pizzo, P.; Fasolato, C. Presenilin-2 dampens intracellular $\mathrm{Ca}^{2+}$ stores by increasing $\mathrm{Ca}^{2+}$ leakage and reducing Ca2+ uptake. J. Cell. Mol. Med. 2009, 13, 3358-3369. [CrossRef] [PubMed]

22. Pchitskaya, E.; Popugaeva, E.; Bezprozvanny, I. Calcium signaling and molecular mechanisms underlying neurodegenerative diseases. Cell Calcium 2018, 70, 87-94. [CrossRef] 
23. Green, K.N.; Demuro, A.; Akbari, Y.; Hitt, B.D.; Smith, I.F.; Parker, I.; LaFerla, F.M. SERCA pump activity is physiologically regulated by presenilin and regulates amyloid $\beta$ production. J. Cell Biol. 2008, 181, 1107-1116. [CrossRef] [PubMed]

24. Zeiger, W.; Vetrivel, K.S.; Buggia-Prévot, V.; Nguyen, P.D.; Wagner, S.L.; Villereal, M.L.; Thinakaran, G. Ca ${ }^{2+}$ Influx through Store-operated $\mathrm{Ca}^{2+}$ Channels Reduces Alzheimer Disease $\beta$-Amyloid Peptide Secretion. J. Biol. Chem. 2013, 288, 26955-26966. [CrossRef] [PubMed]

25. Pierrot, N.; Ghisdal, P.; Caumont, A.-S.; Octave, J.-N. Intraneuronal amyloid- $\beta 1-42$ production triggered by sustained increase of cytosolic calcium concentration induces neuronal death. J. Neurochem. 2004, 88, 1140-1150. [CrossRef] [PubMed]

26. Crestini, A.; Piscopo, P.; Iazeolla, M.; Albani, D.; Rivabene, R.; Forloni, G.; Confaloni, A. Rosuvastatin and Thapsigargin Modulate $\gamma$-Secretase Gene Expression and APP Processing in a Human Neuroglioma Model. J. Mol. Neurosci. 2011, 43, 461-469. [CrossRef]

27. Al-Mousa, F.; Michelangeli, F. Some Commonly Used Brominated Flame Retardants Cause Ca Ca ${ }^{2+}$-ATPase Inhibition, Beta-Amyloid Peptide Release and Apoptosis in SH-SY5Y Neuronal Cells. PLoS ONE 2012, 7, e33059. [CrossRef]

28. Putney, J.W. Forms and functions of store-operated calcium entry mediators, STIM and Orai. Adv. Biol. Regul. 2018, 68, 88-96. [CrossRef]

29. Dong, H.; Zhang, Y.; Song, R.; Xu, J.; Yuan, Y.; Liu, J.; Li, J.; Zheng, S.; Liu, T.; Lu, B.; et al. Toward a Model for Activation of Orai Channel. iScience 2019, 16, 356-367. [CrossRef]

30. Yen, M.; Lewis, R.S. Numbers count: How STIM and Orai stoichiometry affect store-operated calcium entry. Cell Calcium 2019, 79, 35-43. [CrossRef]

31. Hoth, M.; Penner, R. Depletion of intracellular calcium stores activates a calcium current in mast cells. Nature 1992, 355, 353-356. [CrossRef] [PubMed]

32. Barak, P.; Parekh, A.B. Signaling through $\mathrm{Ca}^{2+}$ Microdomains from Store-Operated CRAC Channels. Cold Spring Harb. Perspect. Biol. 2020, 12, a035097. [CrossRef] [PubMed]

33. Hoth, M.; Niemeyer, B.A. The neglected CRAC proteins: Orai2, Orai3, and STIM2. Curr Top Membr. 2013, 71, 237-271. [PubMed]

34. Diez-Bello, R.; Jardin, I.; Salido, G.M.; Rosado, J.A. Orai1 and Orai2 mediate store-operated calcium entry that regulates HL60 cell migration and FAK phosphorylation. Biochim. Biophys. Acta 2017, 1864, 1064-1070. [CrossRef] [PubMed]

35. Vaeth, M.; Yang, J.; Yamashita, M.; Zee, I.; Eckstein, M.; Knosp, C.; Kaufmann, U.; Karoly Jani, P.; Lacruz, R.S.; Flockerzi, V.; et al. ORAI2 modulates store-operated calcium entry and T cell-mediated immunity. Nat. Commun. 2017, 8, 14714. [CrossRef] [PubMed]

36. Tsvilovskyy, V.; Solís-López, A.; Schumacher, D.; Medert, R.; Roers, A.; Kriebs, U.; Freichel, M. Deletion of Orai2 augments endogenous CRAC currents and degranulation in mast cells leading to enhanced anaphylaxis. Cell Calcium 2018, 71, 24-33. [CrossRef] [PubMed]

37. Stegner, D.; Hofmann, S.; Schuhmann, M.K.; Kraft, P.; Herrmann, A.M.; Popp, S.; Höhn, M.; Popp, M.; Klaus, V.; Post, A.; et al. Loss of Orai2-Mediated Capacitative $\mathrm{Ca}^{2+}$ Entry Is Neuroprotective in Acute Ischemic Stroke. Stroke 2019, 50, 3238-3245. [CrossRef]

38. Clemens, R.A.; Lowell, C.A. CRAC channel regulation of innate immune cells in health and disease. Cell Calcium 2019, 78, 56-65. [CrossRef]

39. Yan, J.; Zhao, W.; Gao, C.; Liu, X.; Zhao, X.; Wei, T.; Gao, A.Z. Leucine-rich repeat kinase 2 regulates mouse dendritic cell migration by ORAI2. FASEB J. 2019, 33, 9775-9784. [CrossRef]

40. Feske, S. CRAC channels and disease-From human CRAC channelopathies and animal models to novel drugs. Cell Calcium 2019, 80, 112-116. [CrossRef]

41. Lu, B.; Fivaz, M. Neuronal SOCE: Myth or Reality? Trends Cell Biol. 2016, 26, 890-893. [CrossRef] [PubMed]

42. Kraft, R. STIM and ORAI proteins in the nervous system. Channels 2015, 9, 245-252. [CrossRef] [PubMed]

43. Wegierski, T.; Kuznicki, J. Neuronal calcium signaling via store-operated channels in health and disease. Cell Calcium 2018, 74, 102-111. [CrossRef] [PubMed]

44. Berna-Erro, A.; Braun, A.; Kraft, R.; Kleinschnitz, C.; Schuhmann, M.K.; Stegner, D.; Wultsch, T.; Eilers, J.; Meuth, S.G.; Stoll, G.; et al. STIM2 Regulates Capacitive $\mathrm{Ca}^{2+}$ Entry in Neurons and Plays a Key Role in Hypoxic Neuronal Cell Death. Sci. Signal. 2009, 2, ra67. [CrossRef] [PubMed] 
45. Moccia, F.; Zuccolo, E.; Soda, T.; Tanzi, F.; Guerra, G.; Mapelli, L.; Lodola, F.; D’Angelo, E. Stim and Orai proteins in neuronal $\mathrm{Ca}^{2+}$ signaling and excitability. Front. Cell. Neurosci. 2015, 9, 153. [CrossRef] [PubMed]

46. Zhang, H.; Sun, S.; Wu, L.; Pchitskaya, E.; Zakharova, O.; Fon Tacer, K.; Bezprozvanny, I. Store-Operated Calcium Channel Complex in Postsynaptic Spines: A New Therapeutic Target for Alzheimer's Disease Treatment. J. Neurosci. 2016, 36, 11837-11850. [CrossRef]

47. Kwon, J.; An, H.; Sa, M.; Won, J.; Shin, J.I.; Lee, C.J. Orai1 and Orai3 in Combination with Stim1 Mediate the Majority of Store-operated Calcium Entry in Astrocytes. Exp. Neurobiol. 2017, 26, 42-54. [CrossRef]

48. Dou, Y.; Xia, J.; Gao, R.; Gao, X.; Munoz, F.M.; Wei, D.; Tian, Y.; Barrett, J.E.; Ajit, S.; Meucci, O.; et al. Orai1 Plays a Crucial Role in Central Sensitization by Modulating Neuronal Excitability. J. Neurosci. 2018, 38, 887-900. [CrossRef]

49. Pizzo, P.; Burgo, A.; Pozzan, T.; Fasolato, C. Role of capacitative calcium entry on glutamate-induced calcium influx in type-I rat cortical astrocytes. J. Neurochem. 2001, 79, 98-109. [CrossRef]

50. Okubo, Y.; Iino, M.; Hirose, K. Store-operated $\mathrm{Ca}^{2+}$ entry-dependent $\mathrm{Ca}^{2+}$ refilling in the endoplasmic reticulum in astrocytes. Biochem. Biophys. Res. Commun. 2020, 522, 1003-1008. [CrossRef]

51. Toth, A.B.; Hori, K.; Novakovic, M.M.; Bernstein, N.G.; Lambot, L.; Prakriya, M. CRAC channels regulate astrocyte $\mathrm{Ca}^{2+}$ signaling and gliotransmitter release to modulate hippocampal GABAergic transmission. Sci. Signal. 2019, 12, eaaw5450. [CrossRef] [PubMed]

52. Bandara, S.; Malmersjo, S.; Meyer, T. Regulators of Calcium Homeostasis Identified by Inference of Kinetic Model Parameters from Live Single Cells Perturbed by siRNA. Sci. Signal. 2013, 6. [CrossRef]

53. Oksanen, M.; Petersen, A.J.; Naumenko, N.; Puttonen, K.; Lehtonen, Š.; Gubert Olivé, M.; Shakirzyanova, A.; Leskelä, S.; Sarajärvi, T.; Viitanen, M.; et al. PSEN1 Mutant iPSC-Derived Model Reveals Severe Astrocyte Pathology in Alzheimer's Disease. Stem Cell Rep. 2017, 9, 1885-1897. [CrossRef] [PubMed]

54. Kipanyula, M.J.; Contreras, L.; Zampese, E.; Lazzari, C.; Wong, A.K.C.; Pizzo, P.; Fasolato, C.; Pozzan, T. Ca ${ }^{2+}$ dysregulation in neurons from transgenic mice expressing mutant presenilin 2. Aging Cell 2012, 11, 885-893. [CrossRef]

55. Oberstein, T.J.; Spitzer, P.; Klafki, H.-W.; Linning, P.; Neff, F.; Knölker, H.-J.; Lewczuk, P.; Wiltfang, J.; Kornhuber, J.; Maler, J.M. Astrocytes and microglia but not neurons preferentially generate N-terminally truncated A $\beta$ peptides. Neurobiol. Dis. 2015, 73, 24-35. [CrossRef] [PubMed]

56. Frost, G.R.; Li, Y.-M. The role of astrocytes in amyloid production and Alzheimer's disease. Open Biol. 2017, 7, 170228. [CrossRef]

57. Mostafavi, S.; Gaiteri, C.; Sullivan, S.E.; White, C.C.; Tasaki, S.; Xu, J.; Taga, M.; Klein, H.-U.; Patrick, E.; Komashko, V.; et al. A molecular network of the aging human brain provides insights into the pathology and cognitive decline of Alzheimer's disease. Nat. Neurosci. 2018, 21, 811-819. [CrossRef]

58. Ourdev, D.; Schmaus, A.; Kar, S. Kainate Receptor Activation Enhances Amyloidogenic Processing of APP in Astrocytes. Mol. Neurobiol. 2019, 56, 5095-5110. [CrossRef]

59. Zhao, J.; O'Connor, T.; Vassar, R. The contribution of activated astrocytes to A $\beta$ production: Implications for Alzheimer's disease pathogenesis. J. Neuroinflamm. 2011, 8, 150. [CrossRef]

60. Sil, S.; Hu, G.; Liao, K.; Niu, F.; Callen, S.; Periyasamy, P.; Fox, H.S.; Buch, S. HIV-1 Tat-mediated astrocytic amyloidosis involves the HIF-1 $\alpha$ /lncRNA BACE1-AS axis. PloS Biol. 2020, 18, e3000660. [CrossRef]

61. Hoover, P.J.; Lewis, R.S. Stoichiometric requirements for trapping and gating of $\mathrm{Ca}^{2+}$ release-activated $\mathrm{Ca}^{2+}$ (CRAC) channels by stromal interaction molecule 1 (STIM1). Proc. Natl. Acad. Sci. USA 2011, 108, 13299-13304. [CrossRef] [PubMed]

62. Alansary, D.; Kilch, T.; Holzmann, C.; Peinelt, C.; Hoth, M.; Lis, A. The Minimal Requirements to Use Calcium Imaging to Analyze ICRAC. Cold Spring Harb. Protoc. 2014, 2014, pdb.prot073262. [CrossRef] [PubMed]

63. Suzuki, K.; Kimura, T.; Shinoda, H.; Bai, G.; Daniels, M.J.; Arai, Y.; Nakano, M.; Nagai, T. Five colour variants of bright luminescent protein for real-time multicolour bioimaging. Nat. Commun. 2016, 7, 13718. [CrossRef] [PubMed]

64. Haugabook, S.; Yager, D.; Eckman, E.; Golde, T.; Younkin, S.; Eckman, C. High throughput screens for the identification of compounds that alter the accumulation of the Alzheimer's amyloid $\beta$ peptide (A $\beta)$. J. Neurosci. Methods 2001, 108, 171-179. [CrossRef]

65. Chen, T.-W.; Wardill, T.J.; Sun, Y.; Pulver, S.R.; Renninger, S.L.; Baohan, A.; Schreiter, E.R.; Kerr, R.A.; Orger, M.B.; Jayaraman, V.; et al. Ultrasensitive fluorescent proteins for imaging neuronal activity. Nature 2013, 499, 295-300. [CrossRef] 
66. Ciscato, F.; Filadi, R.; Masgras, I.; Pizzi, M.; Marin, O.; Damiano, N.; Pizzo, P.; Gori, A.; Frezzato, F.; Chiara, F.; et al. Hexokinase 2 displacement from mitochondria-associated membranes prompts $\mathrm{Ca}^{2+}$-dependent death of cancer cells. EMBO Rep. 2020, 21, e49117. [CrossRef]

67. Gross, S.A.; Wissenbach, U.; Philipp, S.E.; Freichel, M.; Cavalié, A.; Flockerzi, V. Murine ORAI2 Splice Variants Form Functional $\mathrm{Ca}^{2+}$ Release-activated $\mathrm{Ca}^{2+}$ (CRAC) Channels. J. Biol. Chem. 2007, 282, 19375-19384. [CrossRef] [PubMed]

68. Jaworska, A.; Dzbek, J.; Styczynska, M.; Kuznicki, J. Analysis of calcium homeostasis in fresh lymphocytes from patients with sporadic Alzheimer's disease or mild cognitive impairment. Biochim. Biophys. Acta 2013, 1833, 1692-1699. [CrossRef] [PubMed]

69. Greotti, E.; Fortunati, I.; Pendin, D.; Ferrante, C.; Galla, L.; Zentilin, L.; Giacca, M.; Kaludercic, N.; Di Sante, M.; Mariotti, L.; et al. mCerulean3-Based Cameleon Sensor to Explore Mitochondrial Ca ${ }^{2+}$ Dynamics In Vivo. iScience 2019, 19, 161. [CrossRef]

70. Pascual-Caro, C.; Berrocal, M.; Lopez-Guerrero, A.M.; Alvarez-Barrientos, A.; Pozo-Guisado, E.; Gutierrez-Merino, C.; Mata, A.M.; Martin-Romero, F.J. STIM1 deficiency is linked to Alzheimer's disease and triggers cell death in SH-SY5Y cells by upregulation of L-type voltage-operated $\mathrm{Ca}^{2+}$ entry. J. Mol. Med. 2018, 96, 1061-1079. [CrossRef]

71. Verkhratsky, A.; Parpura, V. Store-operated calcium entry in neuroglia. Neurosci. Bull. 2014, 30, $125-133$. [CrossRef] [PubMed]

72. Kuchibhotla, K.V.; Lattarulo, C.R.; Hyman, B.T.; Bacskai, B.J. Synchronous hyperactivity and intercellular calcium waves in astrocytes in Alzheimer mice. Science 2009, 323, 1211-1215. [CrossRef] [PubMed]

73. Delekate, A.; Füchtemeier, M.; Schumacher, T.; Ulbrich, C.; Foddis, M.; Petzold, G.C. Metabotropic P2Y1 receptor signalling mediates astrocytic hyperactivity in vivo in an Alzheimer's disease mouse model. Nat. Commun. 2014, 5, 5422. [CrossRef] [PubMed]

74. Dolev, I.; Fogel, H.; Milshtein, H.; Berdichevsky, Y.; Lipstein, N.; Brose, N.; Gazit, N.; Slutsky, I. Spike bursts increase amyloid- $\beta 40 / 42$ ratio by inducing a presenilin- 1 conformational change. Nat. Neurosci. 2013, 16, 587-595. [CrossRef]

75. Zoltowska, K.M.; Maesako, M.; Berezovska, O. Interrelationship between Changes in the Amyloid $\beta$ 42/40 Ratio and Presenilin 1 Conformation. Mol. Med. 2016, 22, 329-337. [CrossRef]

76. Galla, L.; Redolfi, N.; Pozzan, T.; Pizzo, P.; Greotti, E. Intracellular Calcium Dysregulation by the Alzheimer's Disease-Linked Protein Presenilin 2. Int. J. Mol. Sci. 2020, 21, 770. [CrossRef]

77. Brini, M.; Marsault, R.; Bastianutto, C.; Alvarez, J.; Pozzan, T.; Rizzuto, R. Transfected Aequorin in the Measurement of Cytosolic $\mathrm{Ca}^{2+}$ Concentration ([Ca $\left.{ }^{2+}\right]$ c). J. Biol. Chem. 1995, 270, 9896-9903. [CrossRef] 